INTER NATIONAL MONETARY FUND
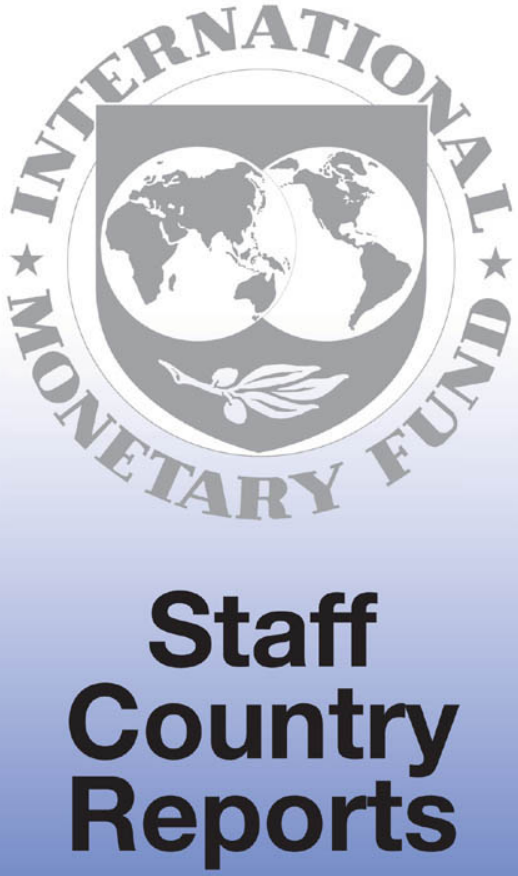


\section{Fiji: 2002 Article IV Consultation-Staff Report; and Statements by the Executive Director and the Authorities for Fiji}

Under Article IV of the IMF's Articles of Agreement, the IMF holds bilateral discussions with members, usually every year. In the context of the 2002 Article IV consultation with Fiji, the following documents have been released and are included in this package:

- the staff report for the 2002 Article IV consultation, prepared by a staff tcam of the IMF, following discussions that ended on May 2, 2002, with the officials of Fiji on cconomic developments and policics. Based on information available at the time of these discussions, the staff report was completed on July 19, 2002. The vicws expressed in the staff report are those of the staff team and do not necessarily reflect the views of the Executive Board of the IMF.

- a Public Information Notice (PIN) summarizing the views of the Executive Board as expressed during its August 9, 2002 discussion of the staff report that concluded the Article IV consultation.

- $\quad$ statements by the Executive Director and the authorities for Fiji.

The document(s) listcd below have been or will be separatcly released.

\section{Selected Issucs Papcr}

The policy of publication of staff reports and other documents allows for the deletion of market-sensitive information

To assist the IMF in evaluating the publication policy, reader comments are invited and may be sent by e-mail to Publicationpolicy@imf.org.

Copies of this report are available to the public from

International Monetary Fund • Publication Services

$70019^{\text {th }}$ Street, N.W. - Washington, D.C. 20431

Telephone: (202) 623-7430 - Telefax: (202) 623-7201

E-mail:publications@imf.org Internet: http://www.imf.org

Price: $\$ 15.00$ a copy

\section{International Monetary Fund \\ Washington, D.C.}


This page intentionally left blank

CInternational Monetary Fund. Not for Redistribution 


\section{INTERNATIONAL MONETARY FUND}

\section{FIJI}

\section{Staff Report for the 2002 Article IV Consultation}

Prepared by the Staff Representatives for the 2002 Consultation with Fiji

Approved by Steven Dunaway and Michael Hadjimichael

July 19,2002

- Consultation discussions were held in Suva during April 22-May 2. The staff team met with Finance and National Planning Minister Kubuabola, Reserve Bank Governor Narube, other government officials, and banking, business, and union representatives. ${ }^{1}$

- Fiji joined the Fund on May 28, 1971. It has accepted the obligations of Article VIII, Sections 2, 3, and 4. The last consultation was concluded by the Board on September 14, 1998. The consultation scheduled for 2000 (under the biennial cycle) was postponed owing to political instability following a coup that toppled the elected government. An informal staff visit was made in June 2001, but a formal consultation was held off pending new elections that were held in September 2001. Following the elections, Fiji's international relations were normalized and international sanctions were lifted.

- The Fijian economy suffered a recession after the coup, but is now recovering in response to a pick-up in tourism, the lifting of sanctions, and fiscal stimulus. Inflation remains low and the current account deficit has narrowed.

- The mission recommended that the focus of macroeconomic policies shift from kick-starting the recovery to implementing a medium-term strategy to raise Fiji's sustainable growth rate. In particular, the mission urged that immediate steps be taken to reduce the large fiscal deficit, primarily through cutting current expenditures. Revenue increases are also likely to be needed to help finance higher public investment.

- Structural reforms should give priority to strengthening public sector management, especially with regard to financial control, and comprehensive restructuring of the sugar industry.

- The mission recommended further easing of exchange controls, especially those pertaining to current transactions, some of which have been assessed to be restrictions inconsistent with Fiji's obligations under the Articles of Agreement. The authorities are advised to establish a clear timetable for removing such restrictions.

- The principal author of this report is Mr. Roger.

' The staff team comprised Messrs Roger (head), Ueda (both APD), and Bhatia (TRE). Mr. Riechel (PFTAC) and Ms. Oo (OED) also participated in the discussions. 


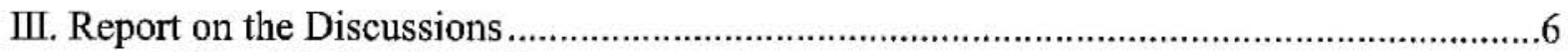

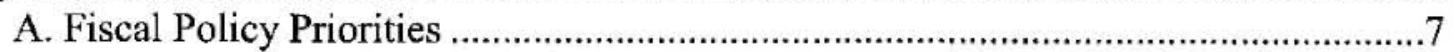

B. Monetary, Exchange Rate, and Financial Sector Policies .......................................8

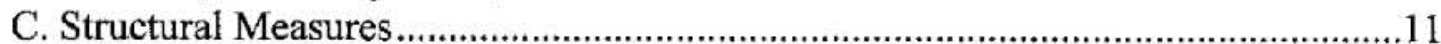

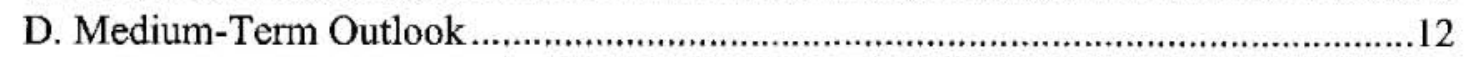

IV. Staff Appraisal

Text Boxes

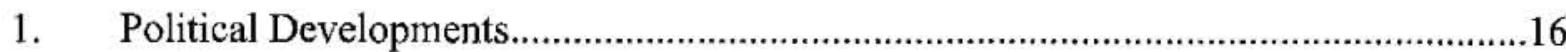

2. $\quad$ Exchange and Capital Controls, 1999-2002 .......................................................17

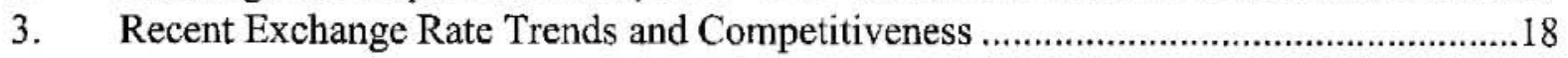

Figures

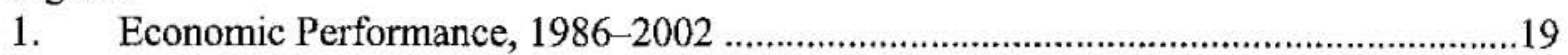

2. Central Government Finances, 1997-2002 …...................................................20

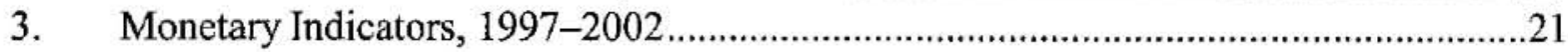

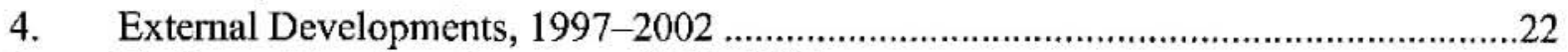

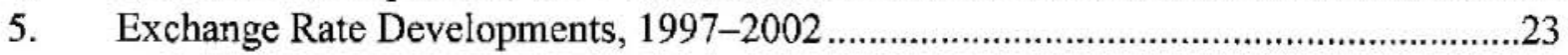

\section{Tables}

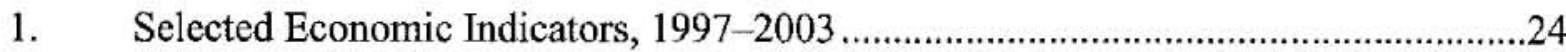

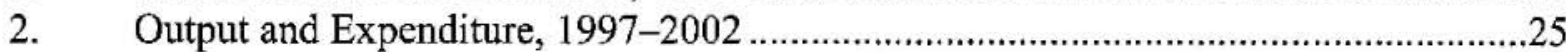

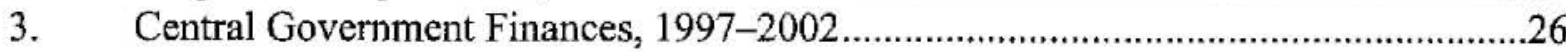

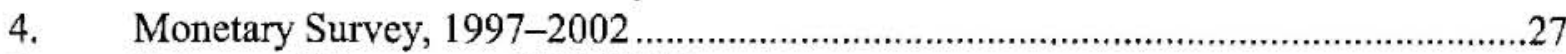

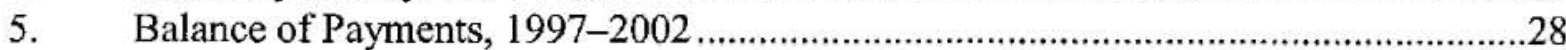

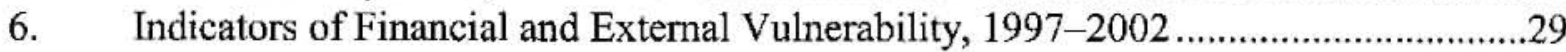

7. Medium-Term Adjustment Scenario, 1998-2007 ...............................................30 


\section{Annexes}

I. Fund Relations

31

II. Relations with the Pacific Financial Technical Assistance Centre.............................33

III. $\quad$ Relations with the World Bank Group ...............................................................34

IV. Relations with the Asian Development Bank ........................................................35

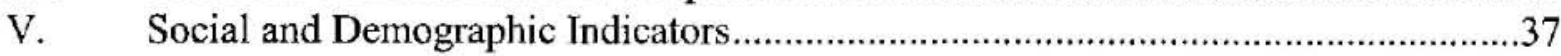

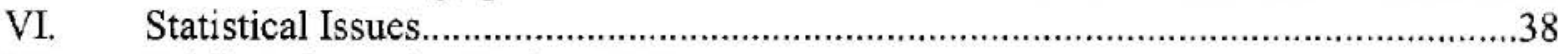

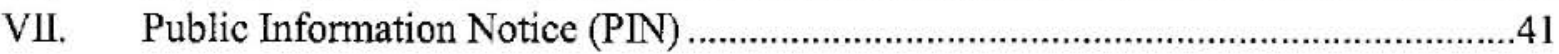




\section{EXECUTIVE SUMMARY}

\section{Economic Setting:}

The Fijian economy is recovering from the after-effects of the 2000 coup. A rebound in the tourism sector and expansionary fiscal policy have been the main drivers of economic growth to date. With the lifting of economic sanctions late in 2001, the economic recovery is becoming more broad-based. Real GDP growth in 2002-03 is projected to be in the range of 4 to 5 percent, while inflation is projected to remain under 3 percent. Earnings from tourism have led to a significant narrowing of the current account deficit, which is projected to fall to 1 percent of GDP by 2003.

\section{Policy Discussions:}

- The staff recommended that immediate action be taken to cut the fiscal deficit in 2002. The deficit could remain close to 6 percent of GDP, in the absence of corrective measures. The staff recommended that the deficit be reduced to around 3 percent of GDP through cuts in wage costs and scaling back of new spending initiatives.

- The staff supported increasing gradually the flexibility of the exchange rate over time. Such flexibility would facilitate the removal of exchange controls and financial sector development. The staff emphasized that movement in this direction will need to be accompanied by fiscal and monetary policies consistent with exchange rate stability, underscoring the need for fiscal consolidation.

- Exchange controls should be liberalized and restrictions eliminated. The wide range of controls still in place is unhelpful to Fiji's efforts to attract foreign investment. Moreover, the staff has determined that some exchange controls constitute restrictions subject to approval under Article VIII. The staff does not recommend approval for the retention of these measures and recommends that the authorities set a clear timetable for their elimination.

- The staff supported the government's medium-term objectives of reducing the government debt GDP ratio and increasing public sector investment in order to raise the economy's sustainable growth rate. To achieve these objectives, the staff recommended cuts in lower priority current spending and selected increases in revenues (e.g., an increase in the VAT rate).

- The staff also endorsed a range of structural reforms. The staff stressed the need to strengthen public sector management, especially financial management, as this will play an important role both in achieving fiscal consolidation and in raising public sector productivity. In the private sector, comprehensive restructuring of the sugar industry is urgent, including a resolution of land issues. Moreover, the staff recommended prompt action to simplify the investment approval process, dismantle price controls, and eliminate distortionary import licenses and quotas. 


\section{BACKGROUND}

1. At the conclusion of the $\mathbf{1 9 9 8}$ Article IV consultation, Directors commended Fiji for its historical record of low inflation, fiscal prudence, and modest external debt. However, they also expressed concern with the recent deterioration in the fiscal balance and stressed the need for wage restraint to realize the gains from the 20 percent devaluation of the Fiji dollar in 1998. They also urged prompt implementation of a credible structural reform agenda, especially for the renewal of agricultural land leases, and the acceleration of privatization and deregulation, to promote private sector growth.

\section{In May 2000, Fiji's elected government was overthrown in a coup. As with} the 1987 coups, the key issue was the longstanding tension between indigenous Fijians and citizens of Indian origin (Box 1). The resulting political turmoil led to the postponement of the 2000 Article IV consultation. ${ }^{2}$ In protest against the coup, the international community applied political and economic sanctions, including postponement of development assistance projects. In addition, Australian and New Zealand trade unions imposed trade sanctions on Fijian goods. Elections were held in September 2001, and won by interim Prime Minister Qarase's indigenous Fijian SDL party. This led to an easing of official sanctions and to the normalization of Fiji's international relations. The domestic political situation also became more settled, although court challenges against the government have not yet been resolved.

\section{RECENT DEVELOPMENTS AND SHORT-TERM OUTLOOK}

\section{Monetary and fiscal policy actions helped to contain the adverse economic} consequences of the coup in $\mathbf{2 0 0 0}$ (Table 1 and Figure 1). Immediately following the coup, the Reserve Bank of Fiji (RBF) increased its lending rates sharply, imposed credit ceilings on bank lending, and tightened exchange controls (Box 2) in order to minimize pressure on the Fiji dollar and protect international reserves. A mini-budget was introduced in July 2000 in anticipation of a sharp decline in tax revenues. Cuts in nonsalary expenditures by 20 30 percent and in civil service wages by $12 \frac{1}{2}$ percent limited the fiscal deficit to $3 \frac{1 / 4}{4}$ percent of GDP. These measures are credited with limiting the fall in consumer and business confidence. As a result, the fall in GDP of $23 / 4$ percent in 2000 was much less than initially feared (Table 2). The decline in output largely reflected sharp declines in tourism earnings and tourism-related investment, and the adverse impact of external sanctions on investment and textile exports. With the slump in tourism earnings in particular, the current account deficit widened to over 6 percent of GDP.

\section{As the political and security situation began to normalize, monetary and fiscal} policies were eased, helping to promote recovery in 2001. Beginning in September 2000, the RBF cut interest rates progressively, eliminated the ceiling on credit growth, and scaled back exchange controls, against a background of subdued inflation pressures and foreign reserves which, although declining, remained above four months of import cover. The 2001

${ }^{2}$ The staff made an informal visit to Fiji in June 2001, but a formal consultation was delayed pending the outcome of elections in September 2001. 
budget, introduced in December 2000, included substantial increases in current and capital expenditure, together with tax cuts. As a result, the fiscal deficit widened sharply, to $6 \frac{1}{2}$ percent of GDP in 2001, and the government debt/GDP ratio rose to 44 percent, compared with 37 percent at end-1999 (Table 3 and Figure 2). Economic activity began to recover in 2001, with real GDP rising by $3 \frac{3}{4}$ percent, reflecting the impact of expansionary fiscal measures and a pick-up in the tourism and garment sectors. In the sugar industry, however, output and employment contracted further in 2001 as land leases expired.

Moreover, private investment-including FDI - remained very weak, owing to persistent uncertainties regarding the longer-term political and economic outlook. Money and credit aggregates reflected this weakness, as broad money fell 3.1 percent in 2001, while domestic credit shrank $2 \frac{1}{2}$ percent, including a $5 \frac{1}{2}$ percent decline in private sector credit (Table 4 and Figure 3).

5. Growth is expected to strengthen in 2002-03. Real GDP is projected by the authorities to rise by $4 \frac{1}{2}$ percent in 2002 , reflecting on-going fiscal stimulus, continued strengthening of the tourism sector, and the resumption of development assistance projects following the lifting of external sanctions. In 2003, real GDP growth is projected to rise temporarily to over 5 percent as the hosting of the South Pacific Games is expected to provide a major boost to tourism sector investment and earnings.

6. Inflation pressures remain subdued. Although labor statistics are poor, higher unemployment--notably in agriculture and the textile sectors-appears to have kept downward pressure on wages, while stability in Fiji's nominal effective exchange rate has kept imported inflation low. The underlying CPI rate fell to under 2 percent in 2001, and to 1 percent in early 2002 . Although some price pressures are likely to emerge as the economy strengthens and as higher world oil prices feed through, CPI inflation is expected to remain in the range of 2 percent to 3 percent in 2002-03.

\section{The current account deficit has narrowed sharply, and the Fiji dollar remains} competitive (Table 5 and Figure 4). The recovery in tourism earnings and an improved balance on private transfers largely accounted for a narrowing of the current account deficit to $3 \frac{1}{2}$ percent of GDP in 2001. In 2002-03, the current account is expected to narrow further as a higher merchandise trade deficit (largely reflecting strengthening demand, especially for capital goods imports) is offset by stronger earnings from tourism. Official reserves are expected to remain adequate, although declining slightly in terms of imports to 4 months of coverage. Since the 20 percent devaluation in 1998, the nominal and real effective exchange rates of the Fiji dollar have been stable, as the Fiji dollar has weakened vis-à-vis the U.S. dollar and strengthened vis-à-vis the Australian and New Zealand dollars (Box 3 and Figure 5).

\section{REPORT ON THE DISCUSSIONS}

8. Fiji's growth performance has for some years been hampered by political instability and adverse effects of government policies on private sector activity. Although performance has been good in some important respects-notably in maintaining low inflation and moderate external indebtedness-real GDP growth over the past five years has averaged only 2 percent per year. Emigration by professionals and skilled workers, 
especially from the Indian ethnic community, in response to the political situation, has contributed significantly to low productivity growth. Economic policies, including exchange and price controls, have also undermined private sector incentives, with the result that private fixed investment averaged only slightly over 4 percent of GDP during the past decade. In these circumstances, the sustainable growth rate has declined.

9. Discussions focused on the policies needed to reverse this trend and achieve the authorities' goal of raising Fiji's sustainable rate of growth. It was agreed that key elements of the strategy will need to include substantial fiscal consolidation; preserving low inflation; increasing the share of government spending on investment and education; easing exchange and price controls and other measures impeding foreign investment; reforming public sector management and financial controls; and restructuring the sugar sector.

\section{A. Fiscal Policy Priorities}

\section{The mission estimated that, without corrective measures, the fiscal deficit} in 2002 would remain around 6 percent of GDP (including asset sales). For the past several years, the fiscal deficit has widened sharply as expenditures have risen while tax revenues have fallen. In 2002, spending is budgeted to rise by $3 / 4$ percent of GDP, bringing the cumulative increase since 1999 to $2 \frac{1}{2}$ percentage points. Revenue (excluding privatization receipts) is projected to decline by $3 / 4$ percentage of GDP - nearly 2 percentage points below the budgeted figure-bringing the cumulative decline to $43 / 4$ percent of GDP since 1999 , largely reflecting cuts in income tax rates and increased tax arrears. ${ }^{3}$ The fiscal deficit in 2002 is expected to remain little changed in terms of GDP only because of the expected receipt of privatization proceeds. Adjusting for these proceeds, the underlying fiscal deficit is expected to rise from $6 \frac{1}{2}$ percent of GDP in 2001 to 8 percent in 2002 . As in previous years, the fiscal deficit is being almost entirely financed domestically, through bond sales to the Fiji National Provident Fund (FNPF). ${ }^{4}$

11. The mission urged immediate action to reduce the $\mathbf{2 0 0 2}$ fiscal deficit. The mission argued that, from a stabilization policy perspective, a large fiscal deficit was not warranted in the current circumstances in which growth was expected to be well above trend. The large deficit would further boost the government debt/GDP ratio to 47 percent of GDP by end2002, making it more difficult subsequently to achieve the government's medium-term target of 40 percent, and undermining the credibility of the authorities' commitment to restoring

${ }^{3}$ The shortfall in tax revenues relative to the budget mainly reflects difficulties in improving tax compliance and reducing arrears. The authorities noted that emigration of trained staff has been an important factor.

${ }^{4}$ The FNPF is a ready buyer of government bonds partly owing to constraints on its ability to invest abroad. Currently, it holds close to three-quarters of outstanding government bonds. With this captive source of finance, the traditional crowding-out effect of the fiscal deficit is limited. 
fiscal sustainability. Moreover, the mission emphasized that privatization proceeds should be used for reducing debt, not for financing the fiscal deficit.

12. The mission recommended a cut in the fiscal deficit to around 3 percent of GDP. A cut of this size would reduce the primary fiscal deficit to close to zero, more appropriate to the cyclical position of the economy, and consistent with real GDP growth of around $3 \frac{3}{4}$ percent of GDP, close to the rate projected in the 2002 budget. The mission recognized that fiscal adjustment on this scale would be challenging, but believed that it could be achieved through reductions in current expenditures by 2 percent of GDP, approximately equally divided between cuts in wage costs (which amount to 11 percent of GDP, or nearly half of current government spending) and the proliferation of nontransparent transfer payment programs in the last two years. Capital spending also should be reduced by 1 percent of GDP through elimination of some programs (including the government's new venture capital initiative) and scaling back of other new initiatives. Additionally, the mission recommended more rigorous expenditure controls to avoid further financial scandals such as the recent fraud at the Ministry of Agriculture, which amounted to $3 / 4$ percent of GDP.

\section{The authorities agreed on the need for fiscal consolidation. They indicated that} continuing staff losses and unfilled vacancies in the public service were cutting wage costs relative to budget allocations. It was also expected that administrative constraints would delay implementation of new programs. As a consequence, actual expenditures could come out at around $1 \frac{1}{2}$ percentage points of GDP below budget. The authorities indicated that they were hesitant to introduce significant additional measures until it was clearer that a recovery was firmly in place. They did assure the mission, however, that its recommendations would be taken seriously into account in the 2003 budget planning, which was to get under way shortly.

\section{B. Monetary, Exchange Rate, and Financial Sector Policies}

\section{The mission agreed with the authorities' assessment that the current stance of} monetary policy is appropriate for $\mathbf{2 0 0 2}$. With inflation low-the headline CPI 12-month inflation rate was 1.2 percent in March, while underlying inflation was near zero--and the international reserves position adequate, the authorities' view was that the RBF's target indicator rate (on 91-day RBF notes), currently at 1.25 percent (since October 2001), should remain low. ${ }^{5}$ The authorities were concerned, however, that credit has continued to shrink and that commercial lending rates remain high in real terms. They attributed this mainly to excessive caution on the part of the main banks. Banks argued that caution was appropriate in view of the ongoing political and economic uncertainties, which were also dampening demand for loans by good quality borrowers. Despite the weakness of private sector credit growth, the mission discouraged the authorities from taking any measures to boost credit

\footnotetext{
${ }^{5}$ The RBF primarily uses open market operations to achieve the RBF 91-day note rate target, and the RBF's Minimum Lending Rate, Rediscount, and Repurchase interest rates are linked to the target rate.
} 
growth which would weaken prudent risk management practices by banks or by public sector lenders.

\section{The banking system appears to be essentially sound, and the regulatory and} supervisory environment is broadly adequate and effective (Table 6). ${ }^{6}$ The Fijian financial system is dominated by a few foreign banks and the FNPF. Although the economic recession led nonperforming loans of commercial banks to rise to 7.1 percent of loans and advances in 2000 , the ratio has declined since then. With little in the way of syndicated lending, banks have had relatively large single-party exposures (typically to tourist resorts), but they are relatively well diversified across sectors. They are also in a position to draw on their foreign parent bank's capital in an emergency, within limits. Consequently, the mission's assessment was that the banking system was not highly vulnerable to external macroeconomic shocks, but domestic political and economic uncertainties were appropriately fostering cautious behavior by the banks. For other financial institutions, asset quality has generally been weaker than for the commercial banks, partly reflecting their greater exposure to loans adversely affected by the problems in the sugar sector. Partly for this reason, and given the RBF's strong reputation and skilled staff, the mission supported proposals to expand its supervisory coverage to other institutions. The RBF is also agreeable to an FSAP mission in 2003. Although Fiji has no offshore banking center, the mission commended the authorities for addressing the issue of money laundering and other financial crimes, notably through the establishment of a Financial Crimes Unit, and their inspection of around 30 percent of bank accounts (by value).

\section{Fiji's monetary framework is based on the long-established peg of the Fiji dollar} to a basket of major trading partner currencies, which provides a nominal anchor for monetary policy. Discussions with the authorities and the private sector suggested that, since the 20 percent devaluation in 1998, the Fiji dollar has remained competitive. Although export earnings were harmed by the trade sanctions and the deterioration of the sugar sector, the lifting of sanctions and strong increases in tourist arrivals have led to a significant improvement in the current account balance that is expected to be sustained through the medium term. Against this background, the mission endorsed the authorities' intention to retain the currency peg, but to move cautiously in the direction of slightly greater exchange rate flexibility in order to facilitate the further relaxation of exchange controls, as well as helping to provide a buffer against external shocks. This is in line with the recommendations of a $1998 \mathrm{MAE}$ technical assistance mission. Initially, a narrow band for exchange rate fluctuation on either side of the central rate is being considered. The mission also agreed that movement in this direction needs to be approached carefully so as to avoid destabilizing exchange rate expectations. ${ }^{7}$

\footnotetext{
${ }^{6}$ See also "Financial System Structure, Supervision, and Performance" in the Selected Issues companion paper.
}

${ }^{7}$ Prior to establishment of a foreign exchange market in which the commercial banks, rather than the $\mathrm{RBF}$, act as market-makers, appropriate risk management and foreign exchange 
17. The mission advised the authorities to eliminate by the end of this year those exchange controls which are not regarded as essential to preventing significant disruptive capital flows. Although Fiji maintains a wide range of exchange controls on both capital and current account transactions, most transactions are approved routinely and rapidly and the tightening following the 2000 coup has been substantially reversed. Nonetheless, the mission suggested that, even if most controls are nonrestrictive in practice, they still detract from Fiji's attractiveness as a destination for foreign investment, a view shared by the commercial banks. In view of the very limited degree of exchange rate flexibility envisaged in the near term, the mission recommended that priority be given to elimination of controls that do not significantly restrict outflows, but that may contribute to deterring inflows, before significantly easing the main controls on capital transactions of domestic residents. ${ }^{8}$ In particular, the mission stressed the importance of eliminating controls relating to the repatriation of dividends and profits by foreign investors. The authorities indicated that they were committed to further liberalizing exchange controls and would take the mission's views into account in the upcoming regular review of exchange controls.

\section{The staff has determined that some exchange control measures constitute} restrictions under Article VIII. These restrictions consist of the monetary limit imposed upon the transferability by nonresidents of dividends abroad and the tax clearance certification requirements imposed on the transfer abroad of profits and dividends and the proceeds of airline ticket sales, and on the making of external debt and maintenance payments. The staff is in the process of seeking the information necessary to clarify the jurisdictional implications of several other measures including the rules governing the making of advance import payments.

\section{The mission agreed that steps toward widening the margin of exchange rate} flexibility around the peg and liberalization of remaining exchange controls should take place against a background of market confidence and supportive macroeconomic policies. In order to ensure that market expectations remain well anchored, fiscal and monetary policies need to be fully consistent with the maintenance of exchange rate stability. In this context, the mission indicated that an early move to fiscal consolidation would signal clearly the authorities' commitment to a sound fiscal strategy. It would also have a beneficial impact on the external current account and allow some build-up of reserves. Although Fiji's official reserves amply cover its external debt obligations, a higher level of reserves would

dealing capacity will need to be put in place. Detailed advice in this regard is being provided to the RBF under MAE technical assistance.

${ }^{8}$ The RBF staff indicated that virtually all transactions are approved and processed within three days; many are cleared with a simple phone call; and transactions limits for many measures are rarely reached. Discussions with banks indicated that limits on repatriation of dividends and profits worked mainly to smooth outflows over a period of time, rather than to prevent them altogether. The main restrictions appear to be on capital transactions by residents. 
provide greater assurance that the RBF would be in a good position to contain exchange rate pressures.

\section{Structural Measures}

\section{The mission emphasized that the public sector management and financial} reforms are essential elements of the medium-term strategy to raise growth and achieve fiscal consolidation. Management reforms are needed to raise public sector productivity directly, as well as to free up resources for productive investment, while financial management reform is essential to ensure that budget priorities and constraints are translated into reality. ${ }^{9}$ The mission expressed particular concern that the first phase of the financial management reforms - the implementation of an online financial monitoring system - is not scheduled for completion until well into 2003, and recommended that interim monitoring arrangements be put in place to improve financial control. The authorities agreed that implementation of reforms needed to be accorded greater urgency and assured the mission that action was being taken to accelerate progress.

\section{The mission advised the authorities to continue with privatization of public} enterprises. In 2001 and 2002, the government sold part of its holdings in Fiji's monopoly supplier of telecommunications for the equivalent of $1 \frac{1}{2}$ percent of GDP, reducing its shareholding to a little over one-third. Shares were sold to Fijian residents and the FNPF, which now owns over half of the enterprise. The planned sale of part of the government's shareholding in Fiji's third largest bank (with 10 percent of banking system deposits), however, has been postponed. Moreover, the authorities indicated that there were no immediate plans for further privatizations, as their priorities are to improve enterprise management and financial control within the public sector, before proceeding with an expanded privatization program. The mission emphasized that the authorities needed to recognize the limits on their ability to add value, especially with regard to management, and not delay privatization.

\section{The mission encouraged the authorities to press ahead urgently with far-} reaching reforms of the sugar industry. Sugar production and profitability in the industry have dropped sharply as leases of land under sugar cultivation have expired. ${ }^{10}$ The contraction of the industry is already adversely affecting Fiji's economic performance-it is estimated that the shrinkage of the sector has cut average annual GDP growth by almost $3 / 4$ percentage points since 2000 . Moreover, migration of rural unemployed is adding to strains on Fiji's urban infrastructure and social fabric. Resolution of the industry's problems will require a breakthrough on contentious issues surrounding the leasing of native lands. In addition, the government's extensive regulation of the industry needs to be overhauled in

\footnotetext{
${ }^{9}$ See "Reform of Public Financial Management, the Public Service, and the Public Enterprises" in the Selected Issues companion paper.
}

${ }^{10}$ See "Sugar Sector Issues" in the Selected Issues companion paper. 
order to improve incentives and profitability. If these problems can be addressed and regulation eased, the mission estimates that recovery of the sugar sector could add an average of a $1 / 2$ percentage point to Fiji's real growth rate over the next several years.

23. Fiji maintains extensive controls on prices. Controls apply to basic foods items, fuel, cigarettes, and a range of services including rents, education fees, and telecoms charges, and cover about one-third of the CPI by expenditure weight. A review of the Prices and Incomes Board in 2001 concluded that a fundamental refocusing of its role was appropriate. The mission recommended that the authorities substantially reduce controls as part of their efforts to increase economic efficiency. The authorities agreed that they would act on the recommendations of the review.

\section{The mission proposed prompt simplification of the foreign direct investment} approvals process, in line with the government's commitment in the 2002 budget. The mission's discussions with the private sector indicated that the complications and delay associated with obtaining approval from a range of different government departments is a significant deterrent to foreign investment. The authorities acknowledged that there had been legitimate complaints regarding the delays, and that they had been slow in addressing the problem, but indicated that changes in the relevant legislation were now being prepared.

\section{Fiji has simplified its tariff structure, and is party to several bilateral, regional,} and multilateral trade agreements. Since 1997, Fiji has reduced its top tariff rate from 35 percent to 27 percent. The number of tariff rate bands has been reduced from 7 in 1998 to 4 currently $(0,3,10$, and 27 percent). Partly as a result, average duty collections have fallen from 15 percent of the value of goods imports in 1998 to just under 11 percent in 2001. The authorities are reviewing import licenses and quotas in order to ensure that they conform to WTO policies to eliminate such restrictions. Fiji participates in a number of preferential trade arrangements. The most important of these is the ACP Sugar Protocol under the Cotonou Agreement, which subsidizes Fijian sugar exports to the European Union. Fiji belongs to several regional groups, mainly aimed at providing preferential access for Pacific island countries to the Australian and New Zealand markets.

\section{The quality, coverage, and timeliness of Fiji's economic and financial statistics}

are fairly good. Fiji has received extensive Fund technical assistance over the years, from both headquarters and the Pacific Financial Technical Assistance Centre. The main areas for improvement on which the authorities are working are the timeliness of merchandise trade statistics; the framework for compiling external debt statistics; the coverage of nonbank financial institutions in the monetary statistics; the compilation of expenditure GDP in the national accounts; and the quality of labor market data.

\section{Medium-Term Outlook}

27. The mission endorsed the main elements of the authorities' medium-term fiscal strategy. These include, in particular, a medium-term target of 40 percent for the central government debt/GDP ratio and raising the target share of government expenditure on investment to 30 percent. In the mission's view, a credible commitment to these objectives 
would play a key role in promoting investor confidence. Substantial fiscal consolidation will be required to achieve these objectives (Table 7), including the establishment of a primary fiscal surplus for several years in order to lower the government debt/GDP ratio from its current level to the target level. In the mission's medium-term scenario, increased public investment spending would be feasible through a combination of increases in tax revenues over their 2001 level of around 2 percentage points of GDP (of which $1 / 2$ percentage point is expected from improved tax compliance resulting from recruitment and training of tax collectors) by 2003 and cuts in current spending of roughly 4 percentage points of GDP by 2007 . Reductions in current spending of this magnitude should be feasible through reduced wage costs resulting from public sector reforms and improved prioritization and efficiency in spending programs (particularly for rural development).

\section{The mission emphasized the need to focus current spending more clearly on} maximizing long-term productivity gains. In this context, the mission pointed to the need for a clearer strategy for rural and agricultural development, especially regarding the sugar sector. Secondly, the mission observed that provision of productivity-enhancing areas of education and health services should not be cut. Thirdly, the mission stressed the importance of reducing the costs of government through substantial improvements in efficiency in the public sector itself.

29. The mission also advised that revenue increases will be required to help finance the desired increases in public investment spending. In particular, the mission suggested that an increase in the VAT rate, from 10 percent currently to 12 percent, should be considered in preference to increasing direct taxes. The authorities observed that the reinstatement of VAT on basic items in 2001 had not been popular, but agreed that this option should not be ruled out in their 2003 budget planning. The mission indicated that the alternatives of even sharper cuts in current spending, or increases in income taxes, would be less conducive to growth and alleviation of poverty.

30. The mission estimated that higher public and private investment could raise the sustainable rate of growth of real GDP to around $31 / 2$ percent. The gradual rise in the share of government spending on investment assumed in the medium-term scenario would boost public investment to 9 percent of GDP by 2007. The scenario also envisages a significant rise in private investment, particularly in the tourism, information technology, and natural resource sectors in response to improved public infrastructure, the easing of exchange controls, and improved business confidence resulting from fiscal consolidation. Total investment is thus projected to rise to an average of 15\%/4 percent of GDP in the 2002-06 period, $3 \frac{1}{4}$ percentage points above the $1996-2001$ average. ${ }^{11}$ Based on studies of the impact of investment on long-term growth, the mission estimates that this would be consistent with the sustainable growth rate of GDP rising to around $3 \frac{1}{2}$ percent over the medium term. ${ }^{12}$

11 Approximately half of the increase in private sector investment is assumed to be financed through FDI inflows and the other half through foreign borrowing.

${ }^{12}$ See "Public Investment and Economic Growth" in the Selected Issues companion paper. 


\section{There are significant uncertainties surrounding the projection scenario. A key} risk to the outlook is that the authorities will delay or only partially implement fiscal consolidation. With higher public debt as a result, the build-up of public investment would be impeded. Failure to pursue fiscal consolidation convincingly would also jeopardize liberalization of exchange controls, undermining the projected recovery of private investment. As a consequence, the pick-up in sustainable growth would be postponed. The second major area of uncertainty concerns the projected increase in sustainable growth. Uncertainty regarding Fiji's political stability could lead to a less positive response of private investment, especially FDI, to fiscal consolidation and higher public investment. In addition, the impact of higher projected investment on the sustainable growth rate might be less than that assumed. In either case, sustainable growth would be lower, making it more difficult to achieve fiscal consolidation. For example, if the growth rate remained at around 2 percent of GDP, as in the past five years, rather than rising to $3 \frac{1}{2}$ percent, while government spending remained at the levels assumed in this projection, then the government debt/GDP ratio, instead of declining to 40 percent, would continue to rise toward 50 percent.

\section{STAFf APPRAISAL}

32. The Fijian economy is recovering from the after-effects of the $\mathbf{2 0 0 0}$ coup. The authorities deserve credit for prompt monetary and fiscal actions taken to contain the adverse economic effects of the crisis. Recovery in the tourism sector and expansionary fiscal policy have been the main drivers of the recovery to date. With the lifting of trade and aid sanctions late in 2001, the recovery is becoming more broad-based.

33. Immediate action should be taken to cut the fiscal deficit in 2002. The staff estimates that the deficit could remain close to 6 percent of GDP, in the absence of corrective measures. This is unsustainable and will undermine efforts to rebuild foreign investor confidence in Fiji. It is also inappropriate in view of the expected strength of economic growth in 2002. The staff recommends that the deficit be reduced significantly, to around 3 percent of GDP in 2002, through a combination of cuts in wage costs and scaling back of new spending initiatives.

34. The staff regards the authorities' monetary policy stance in $\mathbf{2 0 0 2}$ as appropriate. With inflation pressures low and the level of official reserves adequate, the authorities' emphasis on keeping interest rates low in order to support the economic recovery is warranted. Although the banking system experienced an increase in nonperforming loans during the recession in 2000 , these have since declined, and the vulnerability of the banking system to an external shock is assessed as modest.

35. The staff endorses the continued pegging of the Fiji dollar to a basket of trading partner currencies, but also supports the cautious approach being taken toward increasing the flexibility of the exchange rate. The peg of the Fiji dollar has provided an important anchor for Fiji's price performance and financial stability, and the currency is judged to be externally competitive. Somewhat greater exchange rate flexibility, however, would facilitate the removal of exchange controls and financial sector development. Consideration of a slight increase in the scope for exchange rate movements is appropriate, 
and this will need to be accompanied by fiscal and monetary policies consistent with exchange rate stability, underscoring the need for fiscal consolidation.

36. Exchange controls should be liberalized and restrictions eliminated. The wide range of controls still in place is unhelpful to Fiji's efforts to attract foreign investment, and many of these restrictions could be eliminated without risking disruptive capital flows. Moreover, as explained in paragraph 18, exchange restrictions subject to approval under Article VIII arise from the monetary limit imposed upon the transferability by nonresidents of dividends abroad and the tax clearance certification requirements imposed on the transfer abroad of profits and dividends and the proceeds of airline ticket sales, and on the making of external debt and maintenance payments. The staff does not recommend approval for the retention of these measures, and recommends that the authorities set a clear timetable for their elimination.

37. The staff endorses the authorities' medium-term fiscal objectives of reducing the govermment debt/GDP ratio and raising the share of public spending on investment. To achieve these objectives, the staff recommends expenditure cuts and substantial increases in public sector efficiency. In addition, revenue increases will be needed to help finance the increase in public investment expenditure, and the authorities should consider an increase in the VAT rate.

38. Raising the economy's sustainable growth rate will also require structural reforms. Public sector management and financial sector reforms need to be accelerated, as these will play an important role both in achieving fiscal consolidation and in raising public sector productivity. In the private sector, comprehensive restructuring of the sugar industry is urgent, including a resolution to the land issues. The staff encourages the authorities to persevere in their efforts to find workable solutions. In addition, the staff recommends prompt action by the authorities to simplify the investment approvals process, dismantle price controls, and eliminate distortionary import licenses and quotas.

39. Fiji's economic and financial statistics are adequate for effective surveillance purposes. The staff endorses the authorities' efforts to make further improvements in the areas of trade and external debt statistics, expenditure GDP data, and coverage of the monetary statistics.

40. The staff proposes that the next Article IV consultation be conducted on the 24-month cycle. 


\section{Box 1. Fiji: Political Developments}

\section{Background}

From 1874 to 1970 , Fiji was a British colony. Fijians were reluctant to join the labor force and the traditional society of Fiji was maintained by prohibiting sales of land owned by indigenous Fijians. During the colonial era, a large number of indentured workers were imported from India to work on sugar plantations. Their descendants now comprise 44 percent of Fiji's population of 830,000 .

After independence in 1970, Fiji was governed for seventeen years by the Alliance Party (AP), backed mainly by indigenous Fijians. Following the 1987 elections, in which the AP lost office to a coalition of parties mainly backed by the ethnic Indian community, the government was overthrown in two military coups. Major Sitiveni Rabuka, the coup leader, revoked the constitution and declared the island a rcpublic. After the reinstatement of civilian government (composed of only indigenous Fijians) and the introduction of a new constitution in 1990, Rabuka became prime minister in 1992. He was re-appointed prime minister in 1994, and promised to review the 1990 constitution, a process that culminated in the adoption of a new constitution in 1997.

\section{Political Developments 1999-2002}

The May 1999 election - the first under the new constitution - was won by the Fiji Labour Party (FLP), led by Mahendra Chaudhry, an ethnic Indian. Although the FLP won a majority, it formed a "People's Coalition" with two parties backed by indigenous Fijians. The coalition shared nearly 70 percent of the total seats.

In May 2000, the government was overthrown in a coup led by a Fijian nationalist, George Speight. In the ensuing crisis, Parliament was dissolved by the president, Speight was arrested, and the Fijian military installed an interim government led by Laisenia Qarase, an indigenous Fijian banker. Following the coup, various sanctions were applied to Fiji by the international community, including the freezing of technical and financial aid by most Commonwealth countries and the European Union and trade sanctions imposed by Australian and New Zealand trade unions.

In March 2001, the interim government was declared unconstitutional by the Supreme Court, and Qarase was re-appointed to lead a caretaker government until new elections were held in September 2001. In the elections, Qarase's new party, the Fijian United Party (SDL), won 31 seats in the 71 -seat parliament, while the FLP, led by ousted Prime Minister Chaudhry, won 27 seats. To assure a parliamentary majority, the SDL formed a coalition government with the Conservative Alliance, a small, indigenous Fijian party.

Subsequently, the constitutionality of the government was challenged by the FLP, on the grounds that the constitution requires the prime minister to offer ministerial positions to parties that occupy more than 10 percent of parliament seats. In February 2002, the Court of Appcal ruled that the FLP should be included in the govcrnment. Prime Minister Qarase has appealed the case, but the Supreme Court is yet to deliver a ruling.

The international community has followed the political developments carefully to evaluate the timing for the lifting of sanctions. Although international observer tcams validated the 2001 election as free and fair, the challenge to the government's constitutionality has impeded normalization of Fiji's international relations. Australia resumed its full aid program in October 2001, and Fiji was allowed to attend the Commonwealth Heads of Government meeting in March 2002. 


\section{Box 2. Fiji: Exchange and Capital Controls, 1999-2002}

On May 22, 2000, the Reserve Bank of Fiji tightened its foreign exchange controls, with the stated objective of safeguarding official forcign exchange reserves in the wake of the coup. The measures affect current-account transactions and capital outflows. They include:

- Suspension of offshore investments by the Fiji National Provident Fund (FNPF) and other resident nonbank financial institutions (NBFIs), companies, and individuals;

- Suspension of forward foreign exchange contracts of commercial banks;

- Reduction in the number of classes of foreign currency transactions permitted to be executed by commercial banks without reference to the RBF ("delegated facilities");

- Lowering of the amounts up to which transactions under the remaining delegated facilities were permitted to be executed by commercial banks without reference to the RBF ("delegation limits"); and

- Increased documentation and reporting requirements for all transactions.

The measures introduced on May $22^{\text {nd }}, 2000$ have bcen fine-tuned once, on June 22, 2000, and eased three times, on September 4, 2000, January 1 and January 1, 2002. Selected comparisons between exchange and capital control limits delegated to foreign exchange dealers in effect at the beginning of 1999 and at the beginning of 2002 are shown below. Bona fide transactions above these limits are subject to case-by-case RBF approval. Approval is generally granted promptly, and the public is aware of this policy.

\begin{tabular}{|c|c|c|c|}
\hline \multicolumn{4}{|c|}{ Fiji: Exchange and Capital Controls, 1999-2002 } \\
\hline \multirow[b]{2}{*}{ Transaction } & \multirow{2}{*}{ BoP classification } & \multicolumn{2}{|c|}{$\begin{array}{c}\text { Delegation limits } \\
\end{array}$} \\
\hline & & January 1, 1999 & January 1,2002 \\
\hline $\begin{array}{l}\text { Offshore portfolio } \\
\text { and direct investment } \\
\text { by residents }\end{array}$ & Capital account & $\begin{array}{l}\text { Not delegated. FNPF restricted } \\
\text { to F\$50 mn in } 1999 \text {, other } \\
\text { NBFIs to F } \$ 15 \mathrm{mn} \text { total. } \\
\text { Companies limited to } \\
\text { FS500,000 per application with } \\
\text { a total ceiling of F } \$ 10 \text { million. } \\
\text { Delegated limit for individuals: } \\
\text { F } \$ 20,000 \text { per application. }\end{array}$ & $\begin{array}{l}\text { Not delegated. FNPF restricted } \\
\text { to F\$10 mn in 2002, other } \\
\text { NBFIs to F\$1 mn each, } \\
\text { Companies limited to } \\
\text { F } \$ 100,000 \text { per application. } \\
\text { Delegated limit for individuals: } \\
\text { F\$20,000 per application. }\end{array}$ \\
\hline Withdrawal of FDI & Capital account & F\$100,000 per application & Not delegated \\
\hline Emigrant allowance & Capital account & F\$100,000 per application & FS50,000 per family \\
\hline Principal repayments & Capital account & $\mathrm{F} \$ 100,000$ per application & FS 50,000 per contract \\
\hline Profit repatriation & $\begin{array}{l}\text { IPD \& capital } \\
\text { accounts }\end{array}$ & F\$100,000 per application & $\begin{array}{l}\text { F } \$ 50,000 \text { per company per } \\
\text { annum }\end{array}$ \\
\hline $\begin{array}{l}\text { Insurance/reinsurance } \\
\text { payments offshore }\end{array}$ & $\begin{array}{l}\text { Nonfactor services } \\
\text { account }\end{array}$ & $\begin{array}{l}\text { No limit, subject to Insurance } \\
\text { Act }\end{array}$ & $\begin{array}{l}\text { No limit, subject to Insurance } \\
\text { Act }\end{array}$ \\
\hline $\begin{array}{l}\text { Cancelled hotel } \\
\text { booking refunds }\end{array}$ & $\begin{array}{l}\text { Nonfactor services } \\
\text { account }\end{array}$ & No limit & F $\$ 100,000$ per booking \\
\hline $\begin{array}{l}\text { Travel allowance for } \\
\text { Fiji nationals }\end{array}$ & $\begin{array}{l}\text { Nonfactor services } \\
\text { account }\end{array}$ & No limit & F\$10,000 per return trip \\
\hline $\begin{array}{l}\text { Advance import } \\
\text { payments }\end{array}$ & Trade account & F $\$ 500,000$ per application & FS1 mn per invoice \\
\hline $\begin{array}{l}\text { Payments for } \\
\text { merchanted imports }\end{array}$ & Trade account & $\mathrm{F} \$ 500,000$ per application & F\$1 mn per invoice \\
\hline
\end{tabular}




\section{Box 3. Fiji: Recent Exchange Rate Trends and Competitiveness}

\section{Exchange Rate Trends}

The exchange rate of the Fiji dollar is pegged to a basket of the U.S., Australian, and New Zealand dollars; the Euro; and the Japanese yen. Weights are based on three-year moving averages of Fiji's direction of tradc, are reviewed annually, and are not published. On January 20, 1998, the Fiji dollar was devalued by 20 percent against the basket. Since then, Fiji's nominal effective exchange rate has depreciated modestly, while its real effective rate has remained stable (Figure 5).

Relative stability in Fiji's cffective exchange rate indices, however, has masked large differential movements in bilatcral rates. In the period since Fiji's devaluation, the Australian and New Zealand dollars have depreciated significantly vis-à-vis the U.S. dollar. As a result, the Fiji dollar has appreciated against the Australian and New Zealand dollars in both nominal and real terms, and has depreciated against the U.S, dollar.

\begin{tabular}{|cc|}
\hline $\begin{array}{c}\text { Fiji: Exchange Rates, February } \\
\text { (Cumulative percentage change) }\end{array}$ \\
\hline AS:F\$ & 8.2 \\
NZS:FS & 6.8 \\
US\$:F\$ & -9.4 \\
NEER & -3.1 \\
REER & 0.2 \\
\hline
\end{tabular}

\section{Competitiveness}

Comparative price data at the aggregate level do not suggest that Fiji has suffered a significant loss of export price competitiveness since its devaluation in January 1998. On the bilateral level, movements in cross rates have resulted in some loss of competitiveness vis-àvis Australia and New Zealand, but these have been largely offset by competitiveness gains vis-à-vis the United States.

\begin{tabular}{|lllll|}
\hline \multicolumn{5}{|c|}{$\begin{array}{c}\text { Fiji: Merchandise Exports } \\
\text { and Nonfactor Service Receipts } \\
\text { (Annual percentage change in U.S. dollar value) }\end{array}$} \\
\hline & 1998 & 1999 & 2000 & 2001 \\
\hline Merchandise exports & -24.1 & 25.8 & -0.2 & -8.8 \\
Nonfactor services & -24.6 & 16.0 & -23.1 & -0.9 \\
\hline
\end{tabular}

In their discussions with the mission on external-sector prospects, private-sector representatives uniformly emphasized nonprice clcments over exchange rates as key drivers of competitiveness. Several sectoral

examples were cited.

- Garments. Export orders slumped and buyer relationships were broken as trade sanctions affected the timeliness of Fijian deliveries to Australian and New Zealand markets.

- Sugar. Years of under-investment in farm infrastructure and crushing and processing facilities have resulted in declining cane quality and sugar throughput.

- Tourism. Arrivals were constrained by hotel bed and aircraft seat capacity in $1998-99$ and by political uncertainty more recently, with several large investment projects deferred or cancelled in the wake of the coup.
Fiji: Current Account Receipts in 2001 (In millions of U.S. dollars)

\begin{tabular}{llr}
\hline \multicolumn{2}{c}{ Merchandise exports } & $\mathbf{4 4 1 . 4}$ \\
Of which: & Garments & 143.3 \\
& Sugar & 90.5 \\
& Fish & 42.2 \\
& Gold & 34.9 \\
& Forestry products & 19.3 \\
Services & & $\mathbf{5 1 4 . 4}$ \\
Of which: & Tourism & 228.9 \\
Transfers & & 162.7 \\
Of which: & EU sugar transfers & 49.2 \\
Total & & $\mathbf{1 1 1 8 . 5}$ \\
\hline
\end{tabular}

Key themes that cut across all sectors included infrastructural bottlenecks, notably high-cost and erratic electricity and water supply; labor constraints, particularly in the skilled manpower segment; and political uncertainty, which was highlighted in all meetings as the single largest impediment to private-sector investment and export-oriented activity. 
FGURE 1

FUI

EOONOMCPERPORMANCE, 1986-2002
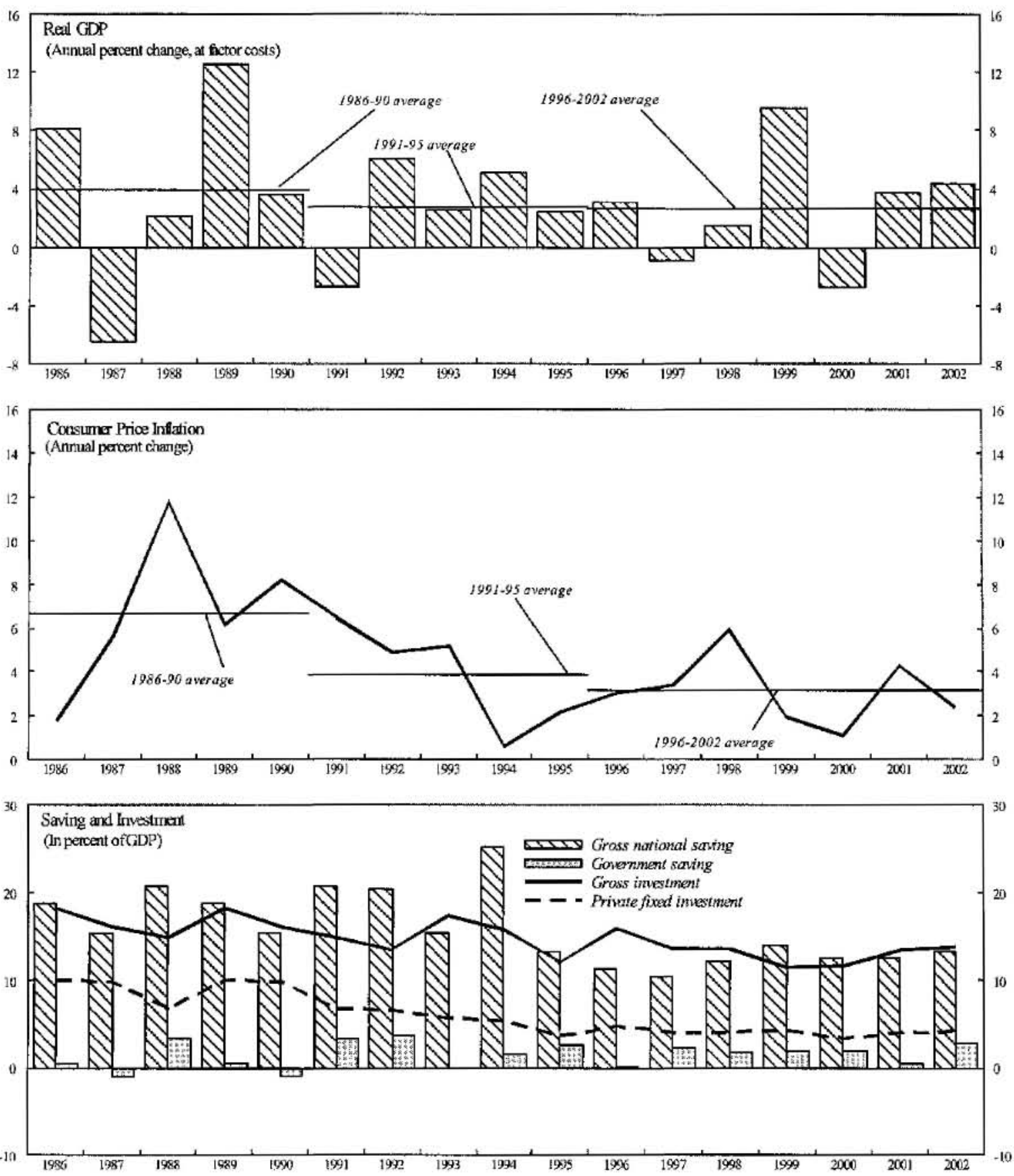

Souroc: Data provided by the Fiji authorities and stafeetimates. 
FGURE2

FII

CENIRAL GOVHRNMENTFNANCES, 1997-2002 I/

(In percent ofGDP)
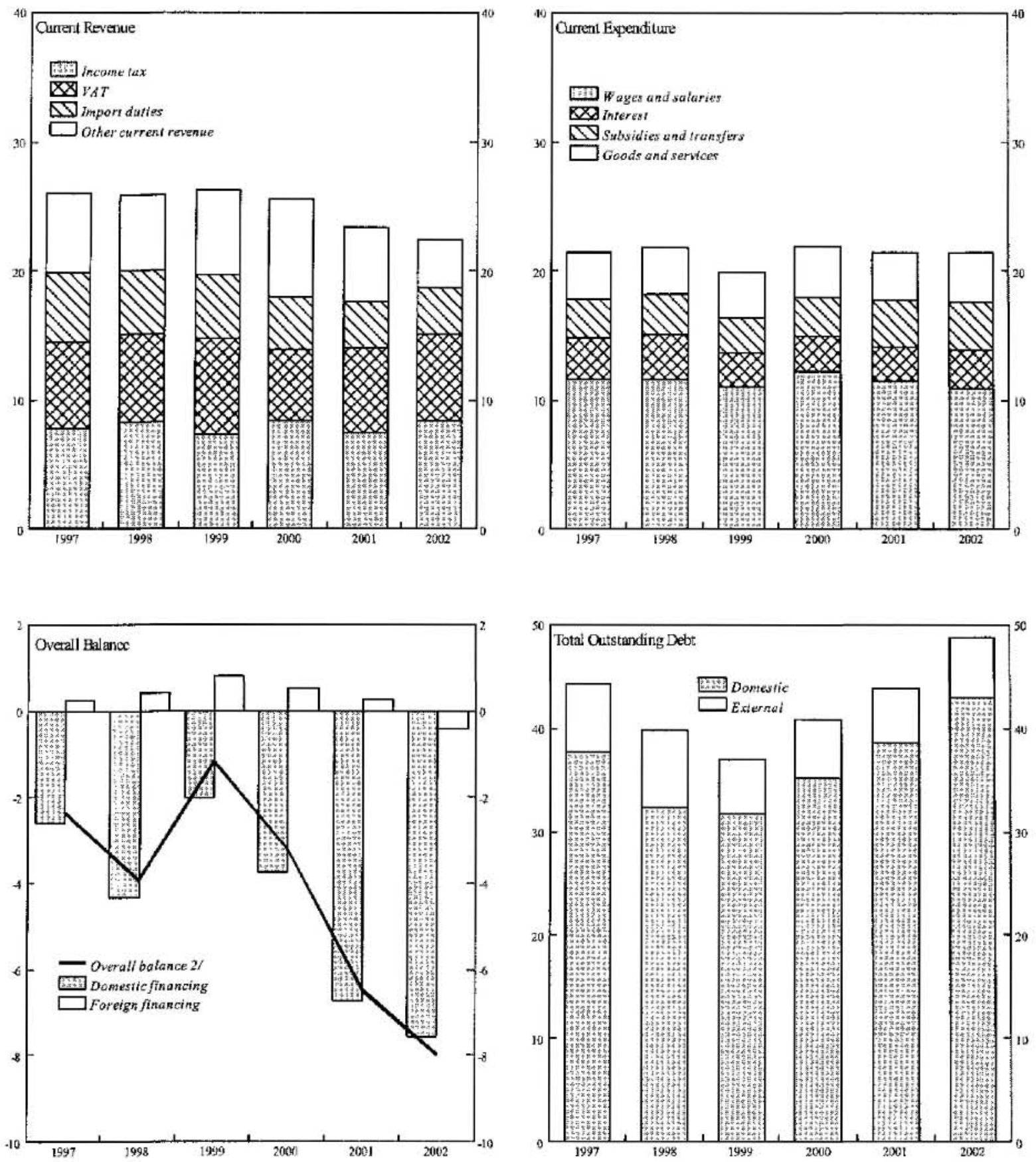

Source: 2002 Budget and Reserve Benk of Fiji, Quartaly Review.

1/ Provisional data for 2001 und budge for 2002.

2t Excludes privatization and National Bank of Fiji (NBF). 
FIGURE3

FUII

MONETARY INDICATORS, 1997-20021
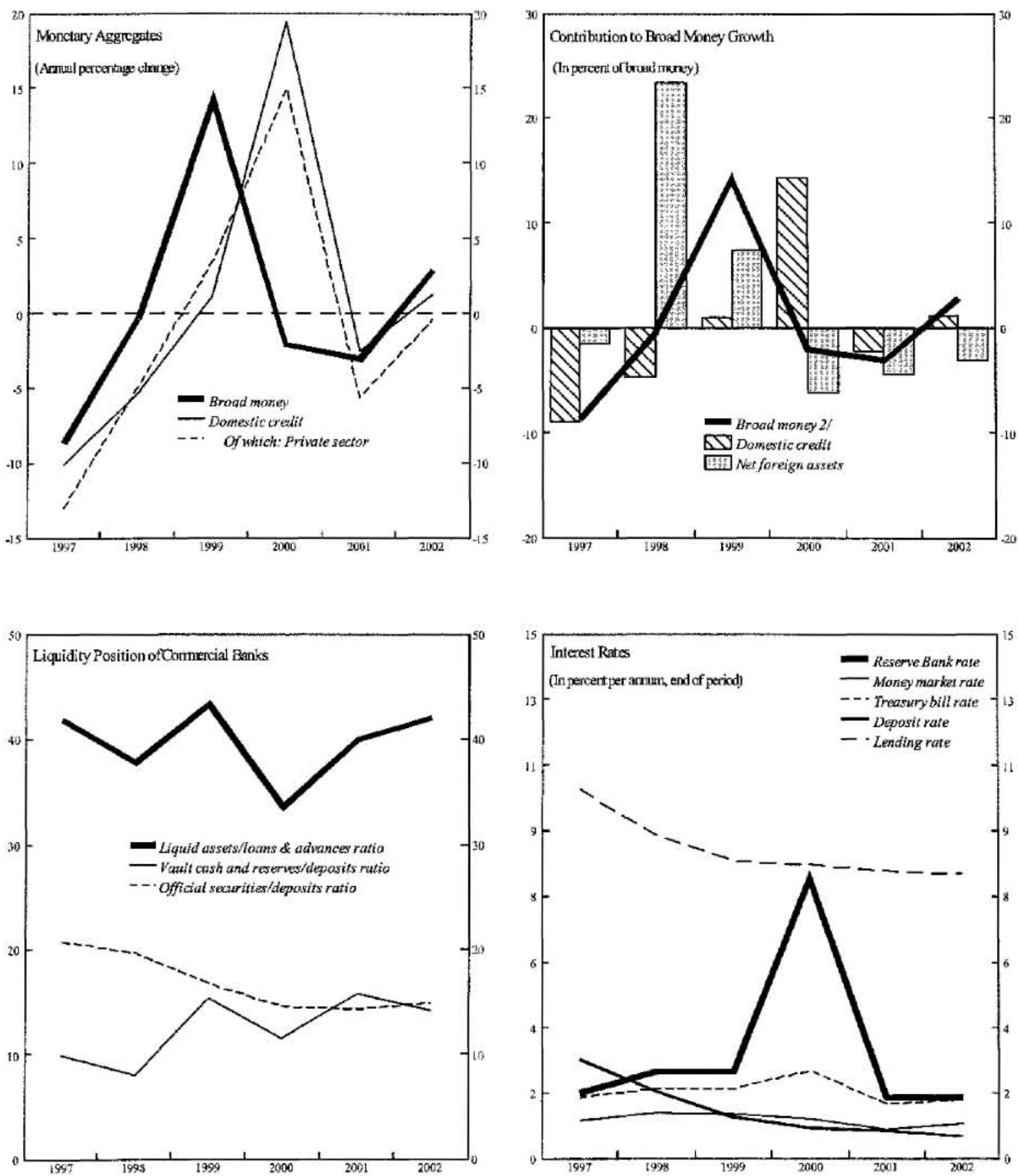

Sourocs: IME, Intenntional Financial Statistios and Money and Banking database; and Rescrve Bank of Fiji, Quarterly Review.

1/ For 2002, data are as of the third quartex of 2002 .

2/ Annual peccertagechange. 
FGURE 4

FLII

EXIERNAL DEVELOPMENIS, 1997-2002 if

(In pacent of GDP, unless otherwise indicatod)
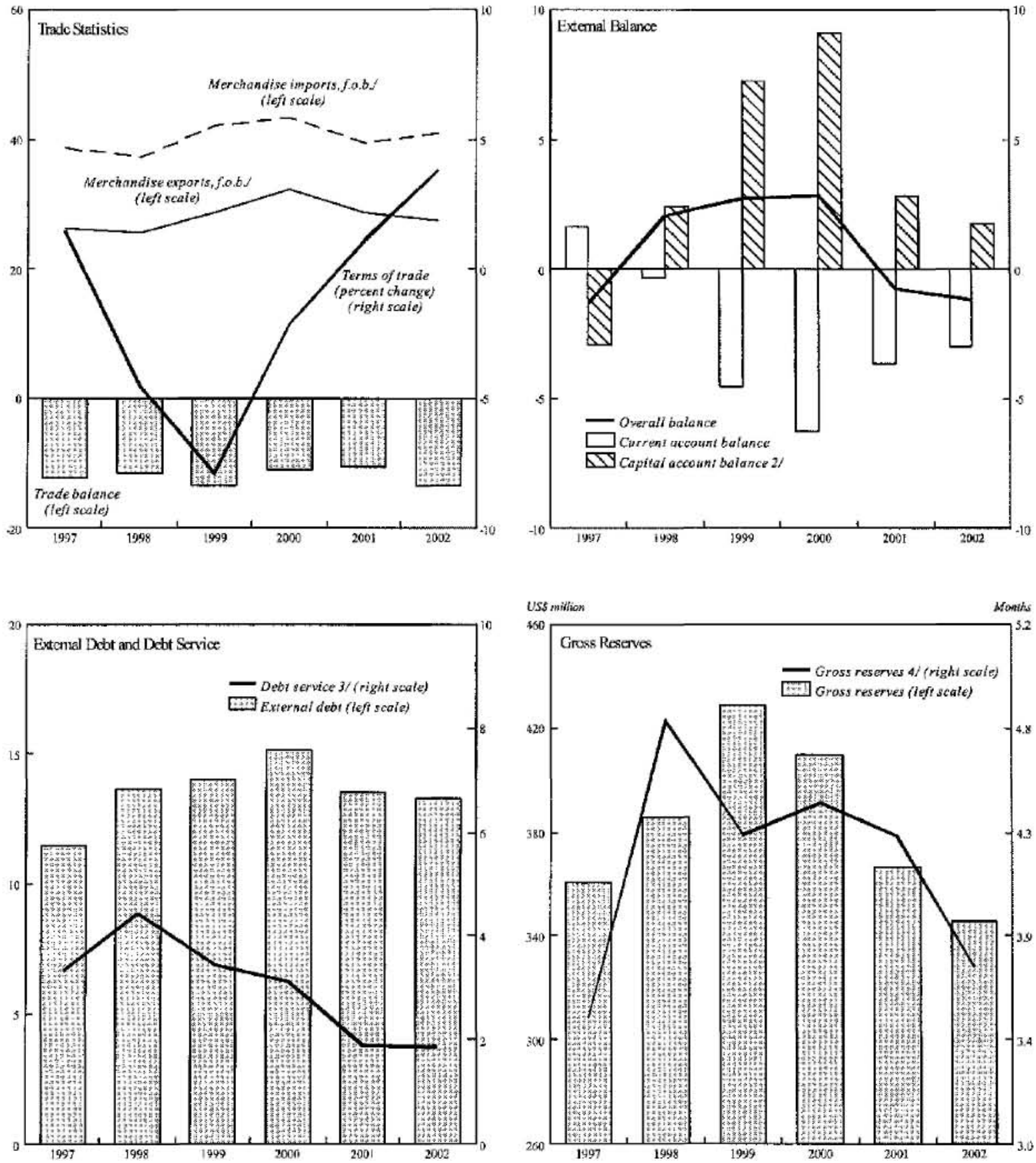

Sourc: IMF, Jntenational Financial Statistics; and 2002 Budget and Reserve Bank offiji, Quarterly Review.

1/ Data fr 2002 are the authorities' projoctions.

$z^{\prime}$ Includes errors and omissions.

3/ In poroent of exports of goods and scrvices.

4/ In months ofimports of goods (fo.b.) and scrvices; adjusted for reexports. 


\section{FIGURE 5}

माग

EXCHANGE RA'TE DEVELOPMENTS, 1997-2002 I/
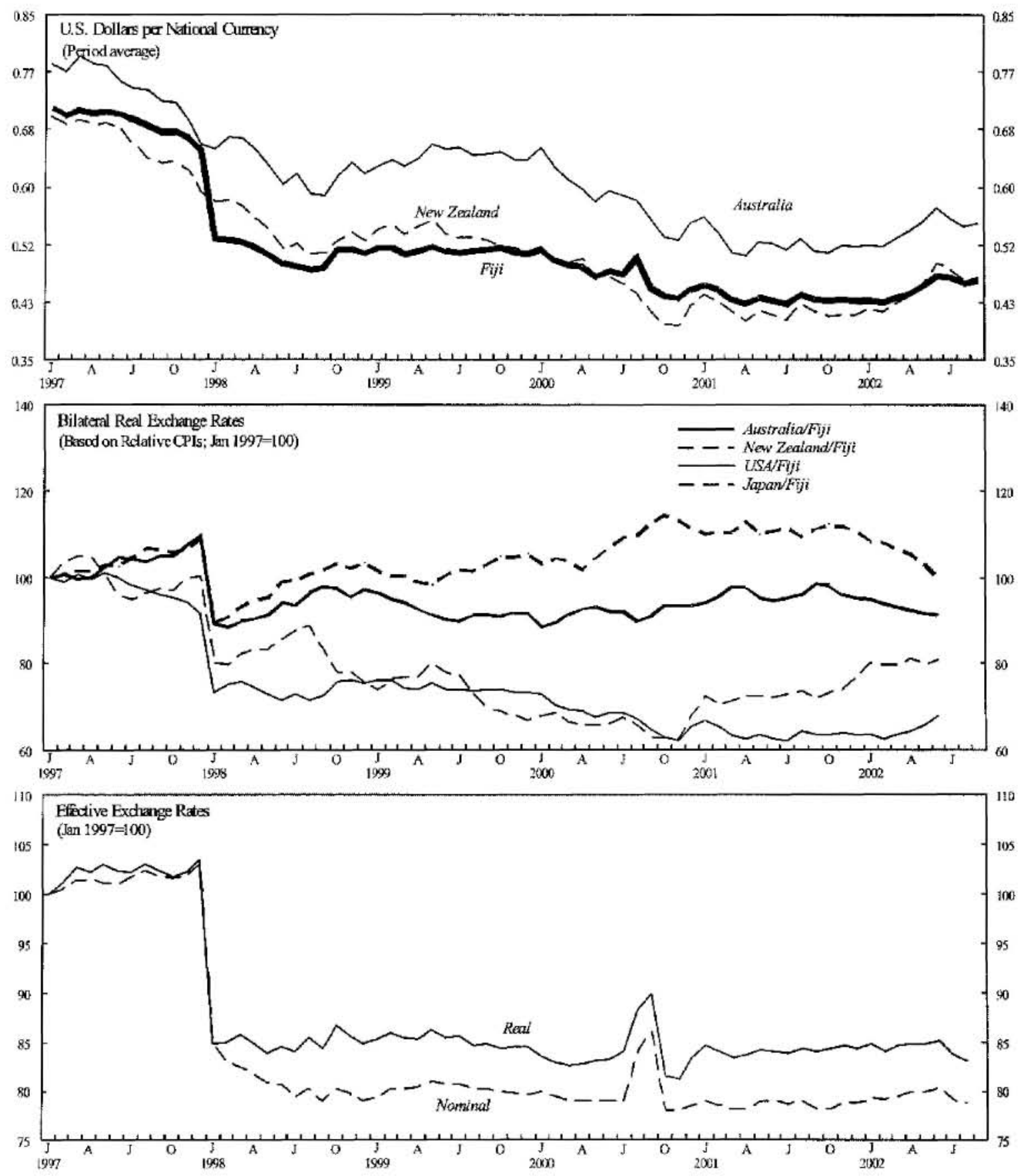

Sources: IMF, International Financial Statistics; Information Notice Systern, and Fund staffcalculations.

1/ The nost recent devaluation took place in knnary 1998 by 20 peroent. 
Table 1. Fiji: Selected Economic Indicators, 1997-2003

Nominal GDP (2001): US\$1,686 million

Population (2001): 829,881

GDP per capita (2001): US\$2,032

Quota: SDR 70,3 million

1997

Consumer prices (average)

Consumer prices (end of period)

Savings and investment (percent of GDP)

Gross national savings

Gross domestic investment

Foreign savings

Central government budget (percent of GDP)

Revenue and grants of which: privatization

Total expenditure $1 f$ of which : capital 1 ;

Overall balance

Underlying balance 1/

Debt outstasding

Money and credit (percent change)

Domestic credit

Government (net)

Official entitics

Private sector

Broad money (M2)

Velocity

Balance of payments (USS millions)

Exports, f.o.b

Imports, f.o.b.

Net nonfactor services and transfers

Net factor income

Current account balance

(In percent of GDP)

Capital account balance $2 /$

Errors and omissions

Overall balance

Gross official reserves (US\$ millions; end of period)

(In months of imports) $3 i$

External debt (USS mn; end of period) 4 (In percent of GDP)

Debt serviec (US\$ millions) $4 /$

(In percent of exports of goods and nonfactor services)

Real effective rate (average) $5 /$

Exchange Rate (FS per US\$: end of period) $6 /$
$-0.9$

$-23.5$

5.9

3.4

2.9

1.5
-26.3
3.3
5.9
8.

9.6

41.6

10.4

2.0

0.2

$$
13.0
$$

11.3

$-1.6$

15.4

15.7
0.3

7.5

12.1

4.5

26.2

0.0

32.9

8.7

$-6.6$

$-2.4$

44.3

34.8

8.5

30.2

4.7

4.6

$-3.9$

39.8

$-53$

$-32.6$

$-6.1$

$-4.9$

$-0.3$

2.4

27.4

0.6

28.

4.7

$-0.6$

$-1.2$

370

1.2

-45.9
-11.2

$-11$

3.4

14.2

2.6

0.0

29.2

4.2

$-3.2$

$-3.2$

40.9

19.5

2131.7

1.1

14.9

$-2.1$

2,4

423

615

268

$-82$

$-6$

$-0.3$

78

$-39$

34

$-28$

$360 \quad 385$

3.5

4,8

$227 \quad 225$

227
11.5
34

34

2.9

112.2

1.55
532

782

267

$-100$

$-84$

$-4.5$

87

47

50

421

4.2

261

14.0

37

3.2

93.5

1.97
2001

Prel.
2003

Proj.

Est. Proj.


Table 2. Fiji: Output and Expenditure, 1997-2002

\begin{tabular}{|c|c|c|c|c|c|c|}
\hline & 1997 & 1998 & 1999 & 2000 & $\begin{array}{l}2001 \\
\text { Prel. }\end{array}$ & $\begin{array}{r}2002 \\
\text { Est. }\end{array}$ \\
\hline & \multicolumn{6}{|c|}{ (Annual percent change at constant 1989 prices) } \\
\hline Real GDP (at constant factor cost) & -0.9 & 1.5 & 9.6 & -2.8 & 3.8 & 4.4 \\
\hline Agriculture & -13.0 & -7.0 & 16.0 & -0.9 & 1.7 & 0.5 \\
\hline Sugar & -23.5 & -26.3 & 416 & -7.5 & -7.1 & -4.0 \\
\hline Nonsugar agriculture & -5.6 & 3.9 & 5.7 & 2.7 & 6.0 & -0.9 \\
\hline Of which: subsistence & 1.5 & 1.3 & 1.1 & 0.5 & 1.4 & 1.0 \\
\hline Manufacturing & -0.8 & 4.8 & 9.6 & -6.2 & 11.5 & 1.5 \\
\hline Nonsugar manufacturing & 5.8 & 11.3 & 5.3 & -6.1 & 15.1 & -0.9 \\
\hline Electricity and water & 2.6 & 3.4 & 9.9 & -2.4 & 4.3 & 5.1 \\
\hline Building and construction & 7.0 & 14.9 & 5.6 & -11.5 & -0.4 & 5.4 \\
\hline Distribution (incl. tourism) & 2.5 & 6.3 & 9.9 & 3.6 & 3.5 & 5.0 \\
\hline Wholesale and retail trade & 2.2 & 6.0 & 10.0 & 9.5 & 3.7 & 5.0 \\
\hline Hotels, cafes, etc. & 4.2 & 7.3 & 9.7 & -23.8 & 2.7 & 4.6 \\
\hline Transportation and communications & 4.6 & 5.8 & 15.8 & -10.8 & 2.8 & 5.4 \\
\hline \multirow[t]{2}{*}{ Finance and insurance } & -6.8 & -0.6 & 7.3 & -2.0 & -4.0 & 0.5 \\
\hline & \multicolumn{6}{|c|}{ (As a percent of GDP at current market prices) } \\
\hline Nominal GDP (at current market prices) & 100.0 & 100.0 & 100.0 & 100.0 & 100.0 & 100.0 \\
\hline Final Consumption & 88.7 & 86.7 & 84.8 & 81.5 & 87.8 & 86.8 \\
\hline Private $\mathrm{J} /$ & 72.1 & 69.2 & 68.8 & 64.0 & 71.3 & 71.3 \\
\hline Government & 16.6 & 17.5 & 16.1 & 17.4 & 16.4 & 15.5 \\
\hline Gross capital formation & 11,3 & 15.7 & 12.1 & 12.1 & 12.8 & 13.8 \\
\hline Fixed Investment & 10.0 & 14.5 & 11.0 & 10.9 & 11.8 & 12.8 \\
\hline Public & 6.4 & 10.7 & 6.1 & 7.1 & 7.5 & 8.5 \\
\hline Private & 3.7 & 3.8 & 4.9 & 3.8 & 4.3 & 4.3 \\
\hline Change in stocks & 1.3 & 1.2 & 1.1 & 1.1 & 1.0 & 1.0 \\
\hline Net exports & 0,0 & -2.5 & 3.1 & 6.5 & -0.6 & -0.7 \\
\hline Exports of goods and nonfactor services & 57.7 & 56.0 & 57.9 & 58.1 & 57.7 & 58.4 \\
\hline Imports of goods and nonfactor services & 57.7 & 58.4 & 54.7 & 51.6 & 58.3 & 59.0 \\
\hline National savings & 13.0 & 15.4 & 7.5 & 5.8 & 9.2 & 10.9 \\
\hline Public & 1.9 & 0.5 & 2.9 & 0.5 & -1.3 & 1.9 \\
\hline Private & 11.1 & 14.9 & 4.7 & 5.2 & 10.5 & 8.9 \\
\hline Foreign savings & -1.6 & 0.3 & 4.5 & 6.3 & 3.6 & 2.9 \\
\hline \multicolumn{7}{|l|}{ Mernorandum item: } \\
\hline Consumer prices (percent change; average) & 3.4 & 5.9 & 2.0 & 1.1 & 4.3 & 2.4 \\
\hline
\end{tabular}

Sources: Fiji Islands Bureau of Statistics; and Fund staff estimates.

1) Includes statistical discrepancy. 
Table 3. Fiji: Central Government Finances, 1997-2002

\begin{tabular}{|c|c|c|c|c|c|c|}
\hline & 1997 & 1998 & 1999 & 2000 & 2001 & $\begin{array}{r}2002 \\
\text { Est. }\end{array}$ \\
\hline & \multicolumn{6}{|c|}{ (In millions of Fiji dollars) } \\
\hline Total revenue and grants & 803 & 1141 & 1005 & 911 & 901 & 1004 \\
\hline Tax revenue & 665 & 724 & 789 & 713 & 740 & 771 \\
\hline Non-tax reveriue & 134 & 415 & 214 & 196 & 160 & 231 \\
\hline Of which: privatization & 0 & 280 & 20 & 0 & 0 & 76 \\
\hline Grants & 5 & 3 & 2 & 1 & 0 & 2 \\
\hline Expenditure & 1006 & 990 & 1028 & 1024 & 1149 & 1255 \\
\hline Current & 740 & 835 & 854 & 877 & 946 & 973 \\
\hline Of which: wages and salaries & 355 & 383 & 403 & 429 & 441 & 437 \\
\hline interest & 99 & 114 & 97 & 96 & 100 & 118 \\
\hline Capital & 266 & 156 & 174 & 147 & 202 & 283 \\
\hline Investment & 87 & 103 & 121 & 96 & 126 & 190 \\
\hline Grants and transfers & 178 & 52 & 53 & 51 & 76 & 93 \\
\hline Of which: NBF & 129 & 0 & 0 & 0 & 0 & 0 \\
\hline Overall balance & -202 & 151 & -23 & -113 & -248 & -252 \\
\hline Underlying balance (excl privatization and NBF) & -73 & -129 & -44 & -113 & -248 & -328 \\
\hline Primary balance & -103 & 264 & 74 & -18 & -148 & -134 \\
\hline Primary balance (excl.privatization and NBF) & 26 & -15 & 53 & -18 & -148 & -210 \\
\hline Financing & 202 & -151 & 24 & 113 & 248 & 252 \\
\hline Domestic & 182 & -123 & 32 & 125 & 142 & 234 \\
\hline \multirow[t]{2}{*}{ Forcign } & -7 & -13 & -30 & -18 & -10 & 17 \\
\hline & \multicolumn{6}{|c|}{ (As a percent of GDP) } \\
\hline Total revenue and grants & 26,2 & 34.8 & 27.4 & 26,0 & 23.5 & 24.5 \\
\hline Tax revenue & 21.7 & 22.0 & 21.5 & 20.4 & 19.3 & 18.8 \\
\hline Non-tax revenue & 4.4 & 12.6 & 5.9 & 5.6 & 4.2 & 5.6 \\
\hline Of which: privatization & 0.0 & 8.5 & 0.6 & 0.0 & 0.0 & 1.9 \\
\hline Grants & 0.2 & 0.1 & 0.0 & 0.0 & 0.0 & 0.1 \\
\hline Expenditure & 32.9 & 30.2 & 28.1 & 29,2 & 29.9 & 30.6 \\
\hline Current & 24,2 & 25.4 & 23.3 & 25.0 & 24.7 & 23.7 \\
\hline Of which: wages and salaries & 11.6 & I 1.7 & 11.0 & 12.2 & 11.5 & 10.7 \\
\hline interest & 3.2 & 3.5 & 2.7 & 2.7 & 2.6 & 2.9 \\
\hline Capital & 8.7 & 4.7 & 4.7 & 4.2 & 5.3 & 6.9 \\
\hline Investment & 2.9 & 3.2 & 3.3 & 2.8 & 3.3 & 4.6 \\
\hline Grants and transfers & 5.8 & 1.6 & 1.4 & 1.4 & 2.0 & 2.3 \\
\hline Of which: NBF & 4.2 & 0.0 & 0.0 & 0.0 & 0.0 & 0.0 \\
\hline Overall balance & -6.6 & 4.6 & -0.6 & -3.2 & -6.5 & -6.1 \\
\hline Underlying balance (excl privatization and NBF) & -2.4 & -3.9 & -1.2 & -3.2 & -6.5 & -8.0 \\
\hline Primary Balance & -3.4 & 8.1 & 2.0 & -0.5 & -3.8 & -3.3 \\
\hline Primary Balance (excl privatization and NBF) & 0.9 & -0.5 & 1.5 & -0.5 & -3.8 & -5.1 \\
\hline Financing & 6.6 & -4.6 & 0.6 & 3.2 & 6.5 & 6.1 \\
\hline Domestic & 6.0 & -3.7 & 0.9 & 3.6 & 3.7 & 5.7 \\
\hline Foreign & .0 .2 & -0.4 & -0.8 & -0.5 & $-0,3$ & 0.4 \\
\hline \multicolumn{7}{|l|}{ Memorandum items: } \\
\hline Central govermment debt & 44.3 & 39.8 & 37.0 & 40.9 & 43.8 & 47.4 \\
\hline Domestic & 37.8 & 32.3 & 31.8 & 35.2 & 38.6 & 41.7 \\
\hline External & 6.5 & 7.5 & 5.2 & 5.8 & 5.2 & 5.6 \\
\hline
\end{tabular}


Table 4. Fiji: Monetary Survey, 1997-2002

\begin{tabular}{|c|c|c|c|c|c|c|}
\hline 1997 & 1998 & 1999 & 2000 & \multicolumn{2}{|c|}{2001} & 2002 \\
\hline
\end{tabular}

\begin{tabular}{|c|c|c|c|c|c|c|c|c|c|c|}
\hline \multirow[b]{2}{*}{ Net foreign assets } & \multicolumn{10}{|c|}{ (In millions of Fiji dollars; end of period) } \\
\hline & 505 & 822 & 922 & 828 & 737 & 714 & 730 & 762 & 706 & 685 \\
\hline Domestic credit & 1188 & 1124 & 1137 & 1359 & 1433 & 1387 & 1360 & 1325 & 1389 & 1377 \\
\hline Claims on government (net) & 9 & 6 & 3 & 74 & 126 & 141 & 130 & 123 & 168 & 167 \\
\hline Claims on official entities & 165 & 154 & 137 & 139 & 156 & 132 & 128 & 120 & 113 & 112 \\
\hline Claims on private sector & 1014 & 964 & 997 & 1146 & 1151 & 1113 & 1103 & 1082 & 1108 & 1098 \\
\hline Broad money (M2) & 1359 & 1354 & 1546 & 1514 & 1504 & 1466 & 1466 & 1467 & 1499 & 1508 \\
\hline Narrow money (M1) & 445 & 494 & 694 & 594 & 619 & 598 & 595 & 621 & 640 & 649 \\
\hline Of which: Currency outside banks & 134 & 160 & 190 & 163 & 170 & 172 & 173 & 182 & 182 & 186 \\
\hline Quasi-money $1 /$ & 913 & 860 & 852 & 920 & 885 & 868 & 870 & 846 & 859 & 859 \\
\hline Reserve Bank notes & 150 & 208 & 201 & 372 & 349 & 353 & 326 & 321 & 297 & 294 \\
\hline \multirow[t]{2}{*}{ Other items (net) } & 184 & 384 & 312 & 301 & 317 & 282 & 299 & 298 & 299 & 260 \\
\hline & \multicolumn{10}{|c|}{ (12-month percent change) } \\
\hline Domestic credit & -10.1 & -5.3 & 1.2 & 19.5 & 5.8 & 0.8 & -4.1 & -2.5 & -3.1 & -1.3 \\
\hline Claims on official entities & 12.8 & -6.1 & -11.2 & 1.1 & 21.3 & 6.1 & -10.0 & -13.5 & -27.8 & -15.7 \\
\hline Claims on private sector & -13.0 & -4.9 & 3.4 & 14.9 & -2.3 & -6.9 & -6.3 & -5.6 & -3.7 & -1.9 \\
\hline Broad money (M2) & -8.7 & -0.3 & 14.2 & -2.1 & 2.2 & 2.0 & -1.4 & -3.1 & -0.4 & 0.5 \\
\hline Narrow money (Ml) & -2.4 & 10.9 & 40.6 & -14.5 & 7.6 & 13.1 & 4.3 & 4.6 & 3.4 & 5.5 \\
\hline \multirow[t]{2}{*}{ Quasi-money } & -11.5 & -5.8 & -1.0 & 8.0 & -1.2 & -4.5 & -5.0 & -8.0 & -3.0 & -3.0 \\
\hline & \multicolumn{10}{|c|}{ (12-month change as a percent of $\mathrm{M} 2$ at beginning of period) } \\
\hline Net foreign assets & -1.5 & 23.3 & 7.4 & -6.1 & -3.7 & -3.2 & -1.9 & -4.4 & -2.1 & -1.8 \\
\hline Domestic credit & -9.0 & -4.7 & 1.0 & 14.3 & 5.4 & 0.8 & -3.9 & -2.3 & -2.9 & -1.2 \\
\hline \multicolumn{11}{|l|}{ Memorandum items: } \\
\hline Money velocity (M2) 21 & 2.2 & 2.4 & 2.6 & 2.4 & $\ldots$ & $\cdots$ & $\ldots$ & 2.6 & $\ldots$ & $\ldots$ \\
\hline Moncy multiplier (M2) 3/ & 5.2 & 4.9 & 3.6 & 4.3 & 4.6 & 4.5 & 4.3 & 3.5 & 3.9 & 3.7 \\
\hline Reserve money (12-month percent change) & 5.0 & 6.3 & 56.8 & -18.9 & 17.8 & 15.2 & 8.6 & 19.3 & 18.8 & 26.8 \\
\hline Liquid assets (in percent of deposits) $4 /$ & 30.6 & 27.7 & 32.0 & 26.1 & 23.2 & 23.5 & 26.1 & 30.1 & 27.9 & 28.7 \\
\hline Deposit interest rate (in percent; end of per & 2.7 & 1.8 & 1.4 & 1.2 & 0.8 & 0.8 & 0.8 & 0.8 & 0.7 & 0.6 \\
\hline Loan interest rate (in percent; end of perio & 10.2 & 9.1 & 9.1 & 8.7 & 8.5 & 8.4 & 8.3 & 8.2 & 8.2 & 8.1 \\
\hline Net foreign assets (USS mn.) & 326 & 414 & 469 & 379 & 316 & 306 & 313 & 330 & 311 & 319 \\
\hline
\end{tabular}

Sources: IMF, Economic Information System; and Reserve Bank of Fiji, Quarterly Review.

1/ Includes capital accounts.

2/ Ratio of GDP to average M2.

3/ Ratio of M2 to reserve money.

4/ Commercial banks' vault cash, unremunerated deposits with monetary authorities, and holdings of government and official entity securiti

5/ On savings deposits.

6) Weighted average rate charged by commercial banks on loans. 
Table 5. Fiji: Balance of Payments, 1997-2002

\begin{tabular}{|c|c|c|c|c|c|c|}
\hline & 1997 & 1998 & 1999 & 2000 & $\begin{array}{r}2001 \\
\text { Prelim. }\end{array}$ & $\begin{array}{r}2002 \\
\text { Est. 1/ }\end{array}$ \\
\hline & \multicolumn{6}{|c|}{ (In millions of U.S, dollars) } \\
\hline Trade balance & -262 & -192 & -251 & -183 & -180 & -227 \\
\hline Exports (f,o.b.) $2 /$ & 557 & 423 & 532 & 530 & 484 & 468 \\
\hline Of which: Garments & 169 & 152 & 164 & 156 & 138 & 136 \\
\hline Sugar $2 /$ & 92 & 40 & 71 & 63 & 48 & 44 \\
\hline Gold & 51 & 35 & 39 & 36 & 38 & 37 \\
\hline Imports (f.o.b.) & 819 & 615 & 782 & 714 & 664 & 694 \\
\hline Of which: Oil & 136 & 80 & 139 & 140 & 119 & 122 \\
\hline Services and Income, net & 224 & 95 & 103 & 39 & 27 & 83 \\
\hline Nonfactor services (net) & 296 & 177 & 203 & 79 & 110 & 153 \\
\hline Of which: Travel earnings & 248 & 196 & 224 & 117 & 157 & 170 \\
\hline Factor income & -72 & -82 & -100 & -40 & -83 & -69 \\
\hline Transfer payments, net & 73 & 91 & 63 & 41 & 93 & 103 \\
\hline Private transfers, net & -11 & -7 & -11 & -12 & 41 & 41 \\
\hline Official transfers, net & 84 & 98 & 74 & 54 & 52 & 63 \\
\hline Of which: EU sugar transfer payments & 56 & 83 & 63 & 49 & 49 & 54 \\
\hline (Net service and transfers) & 297 & 186 & 167 & 80 & 120 & 187 \\
\hline Current account & 35 & -6 & -84 & -103 & -61 & -40 \\
\hline Capital flows, net & -27 & 78 & 87 & 105 & 78 & 23 \\
\hline Official, net & -5 & 22 & 54 & -11 & -7 & -7 \\
\hline Other & -15 & -15 & 72 & 95 & 43 & 7 \\
\hline Commercial banks & -8 & 12 & 1 & -11 & 16 & 11 \\
\hline Trade credit & -7 & -27 & 71 & 106 & 27 & -3 \\
\hline Direct Investment & -7 & 70 & -40 & 21 & 43 & 23 \\
\hline Errors and omissions & -36 & -39 & 47 & 45 & -31 & 2 \\
\hline \multirow[t]{2}{*}{ Overall balance } & -28 & 34 & 50 & 47 & -13 & -15 \\
\hline & \multicolumn{6}{|c|}{ (In pereent of GDP) } \\
\hline Trade balance & -12.4 & -11.6 & -13.5 & -11.1 & -10.7 & -13.0 \\
\hline Current account balance & 1.6 & -0.3 & -4.5 & -6.3 & -3.6 & $-2,3$ \\
\hline Overall balance & -1.3 & 2.0 & 2.7 & 2.8 & -0.8 & -0.8 \\
\hline External Debt $3 /$ & 11.5 & 13.6 & 14.0 & 15.1 & 13.6 & 12.9 \\
\hline Debt-service ratio $4 /$ & 2.7 & 4.1 & 3.2 & 2.9 & 1.9 & 1.8 \\
\hline \multicolumn{7}{|l|}{ Meniorandum iterns: } \\
\hline External debt (US\$ mn) & 227 & 225 & 261 & 242 & 225 & 222 \\
\hline Gross official reserves (US\$ mn) & 360 & 385 & 421 & 410 & 366 & 339 \\
\hline In months of imports 4 & 3.5 & 4.8 & 4.2 & 4.4 & 4.3 & 3.8 \\
\hline
\end{tabular}

Sources: Fiji Islands Bureau of Statistics; Reserve Bank of Fiji; and Pund staff estimates.

1/ Authorities' estimates

2/ Excluding EU sugar transfer payments

3t Total medium- or long-term debt.

4/ in percent of exports of goods and nonfactor services. 
Table 6. Fiji: Indicators of Financial and External Vulnerability, 1997-2002

\begin{tabular}{|c|c|c|c|c|c|c|}
\hline & 1997 & 1998 & 1999 & 2000 & 2001 & $\begin{array}{r}2002 \\
\text { Est. }\end{array}$ \\
\hline \multicolumn{7}{|l|}{ Financial indicators } \\
\hline Central govemment debt (in pcrcent of GDP) & 44.3 & 39.8 & 37.0 & 40.9 & 43.8 & 47.4 \\
\hline Public sector debt (in percent of GDP) I/ & 60.5 & 64.4 & 57.8 & 74.5 & 72.5 & $\ldots$ \\
\hline Broad money (M2) (12-month percent change) & -8.7 & -0.3 & 14.2 & -2.1 & -3.1 & 2.2 \\
\hline Privatc-sector ctedit (12-month percent changc) & -13.0 & -4.9 & 3.4 & 14.9 & -5.6 & 2.2 \\
\hline 91-day Treasury bill rate (in percent; average) $2 t$ & 2.6 & 2.0 & 2.0 & 3.6 & 1.5 & 1.7 \\
\hline Real 91-day Treasury bill rate (in percent; average) $2 / 3 /$ & -0.8 & -3.9 & 0.0 & 2.5 & -2.8 & 0.5 \\
\hline Gross nonperforming loans (as a percent of total loans) $4 / 5 /$ & 6.2 & 3.1 & 3.4 & 7.1 & 6.5 & $\ldots$ \\
\hline Capital-edequacy ratio (in pereent) $4 / 6$ & 12.1 & 11.8 & 10.3 & 11.5 & 16.0 & $\cdots$ \\
\hline Foreign currency-denominated loans (as a percent of total loans) 4 & 4.4 & 0.2 & 0.3 & 0.2 & 0.3 & $\cdots$ \\
\hline Foreign currency-denominated deposits (as a percent of total deposits) 4/ & 9.5 & 7.7 & 10.8 & 9.0 & 10.0 & $\ldots$ \\
\hline Foreign currency-denominated liabilities (as a percent of total liabilitics) 4/ & 7.6 & 7.9 & 10.0 & 7.0 & 8.8 & $\ldots$ \\
\hline Private-sector credit collateralized by real estate (as a percent of total loans) 4 / & 18.7 & 19.5 & 22.5 & 24.6 & 26.0 & $\ldots$ \\
\hline \multicolumn{7}{|l|}{ External indicators } \\
\hline Merchandise exports, foo.b. (12-month percent change in US\$) & -14.5 & -24.1 & 25.8 & -0.2 & -8.8 & -3.4 \\
\hline Merchandise imports, f,o.b. (12-month percent change in USS $)$ & -2.6 & -24.9 & 27.3 & -8.8 & -6.9 & 4.5 \\
\hline Terms of trade (12-month percent change) & 1.5 & -4.5 & $-7,9$ & -2.1 & 1.1 & 3.8 \\
\hline Trade balance (as a percent of GDP) & -12.4 & -11.6 & -13.5 & -11.1 & -10.7 & -13.0 \\
\hline Current account balance (as a percent of GDP) & 1.6 & -0.3 & -4.5 & -6.3 & -3.6 & -2.3 \\
\hline Capital and financial account balance (as a percent of GDP) & -1.3 & 4.7 & 4.7 & 6.4 & 4.7 & 1.3 \\
\hline Of which: Foreign direct investment (as a percent of GDP) & -0.3 & 4.3 & -2.1 & 1.3 & 2.5 & 1.3 \\
\hline Gross official reserves (US\$ millions) & 360 & 385 & 421 & 410 & 366 & 350 \\
\hline Adjusted gross official rescrves (US\$ millions) $7 /$ & 360 & 385 & 421 & 410 & 366 & 350 \\
\hline Monetary authorities short-term cxternal liabilities (USS millions) & 0 & 0 & 0 & 0 & 0 & ... \\
\hline Commercial banks short-erm extermal assets (US\$ millions) & 89 & 136 & 200 & 81 & 84 & $\cdots$ \\
\hline Commcrcial banks short-lerm external liabilities (US\$ millions) & 114 & 98 & 153 & 110 & 117 & $\cdots$ \\
\hline Adjusted official rescrves (in months of imports) $8 f$ & 3.5 & 4.8 & 4.2 & 4.4 & 4.3 & 3.8 \\
\hline Broad money (M2) (as a percent of adjusted reserves) & 2.6 & 1.8 & 1.9 & 1.7 & 1.8 & 1.8 \\
\hline Short-term external ciebt (as a percent of adjusted reserves) 9/ & 52.9 & 39.8 & 51.7 & 46.9 & 53.9 & $\ldots$ \\
\hline Short-term extcrnal debt (as a percent of adjusted reserves) $10 /$ & 62.6 & 48.2 & 57.7 & 50.7 & 58.2 & $\ldots$ \\
\hline Total extemal debt (as a percent of GDP) & 19.7 & 22.9 & 25.7 & 26.4 & 25,1 & ... \\
\hline Total external debt (as a percent of exports) $11 /$ & 33.2 & 39.8 & 41.8 & 43.4 & 44.4 & $\ldots$ \\
\hline External interest payments (as a percent of exports) 11/ 12/ & 0.8 & 0.8 & 0.6 & 0.6 & 0.4 & 0.5 \\
\hline Extemal amortization payments (as a percent of exports) $11 / 12 /$ & 2.6 & 3.6 & 2.8 & 2.5 & 1.6 & 2.1 \\
\hline Exchange rate (F\$ per USS; average) $13 /$ & 1.44 & 1.99 & 1.97 & 2.13 & 2.28 & 2.14 \\
\hline REER (12-rnonth percent change) $14 /$ & 4.9 & -17.1 & 0.3 & -1.5 & 0.5 & 0.7 \\
\hline
\end{tabular}

Sources: Fiji authorities; and Fund staff estimates.

1) Excludes local government debt.

2/ Figure for 2002 is end-March actual.

3/ Nominal yield on 91-day Treastry bills less CPI inflation.

4/ Commercial banks only.

$5 /$ Recognised at 90 days past due.

6/ Tier I and tier II capital as a percent of risk-weighted assets.

7/ Excludes illiquid or cncumbered rescrves.

8/ Imports of goods, f.o.b., and nonfactor services.

9/ By original maturity.

10/ By residual maturity.

11/ Exports of goods, f.o.b., and nonfactor scrvices.

12 / On medium- or long-term debt.

13/ Figure for 2002 is end-May actual.

14/ Calculated from IMF Information Notice System Index, $1990=100$. Figure for 2000 is for January-March. 
Table 7. Fiji: Medium-Term Adjustment Seenario, 1998-2007

(As a percent of GDP, unless otherwise noted)

\begin{tabular}{|c|c|c|c|c|c|c|c|c|c|c|}
\hline & \multirow[b]{2}{*}{1998} & \multirow[b]{2}{*}{1999} & \multirow[b]{2}{*}{2000} & \multirow{2}{*}{$\begin{array}{c}\text { Prel. } \\
2001\end{array}$} & \multicolumn{6}{|c|}{ Projections } \\
\hline & & & & & 2002 & 2003 & 2004 & 2005 & 2006 & $\overline{2007}$ \\
\hline \multicolumn{11}{|l|}{ Output and prices (percent change) } \\
\hline Real GDP (at constant factor cost) & 1.5 & 9.6 & -2.8 & 3.8 & 3.7 & 5.2 & 2.0 & 3.0 & 3.2 & 3.3 \\
\hline Consurner prices (average) & 5.9 & 2.0 & 1.1 & 4.3 & 2.4 & 2.5 & 2.5 & 2.5 & 2.5 & 2.5 \\
\hline \multicolumn{11}{|l|}{ Savings and investunent } \\
\hline National savings & 15.4 & 7.5 & 5.8 & 9.2 & 11.0 & 13.5 & 14.8 & 15.8 & 16.8 & 17.8 \\
\hline Public 1/ & 0.5 & 2.9 & 0.5 & -1.3 & 3.7 & 1.9 & 1.2 & 0.8 & 0.5 & 0.5 \\
\hline Private & 14.9 & 4.7 & 5.2 & 10.5 & 7.3 & 11.6 & 13.6 & 15.0 & 16.3 & 17.3 \\
\hline Gross investment & 15.7 & 12.1 & 12.1 & 12.8 & 13.3 & 14.6 & 15.5 & 16.3 & 16.8 & 17.4 \\
\hline Of which: public fixed iavestment & 10.7 & 6.1 & 7.1 & 7.5 & 7.7 & 7.8 & 8.1 & 8.4 & 8.7 & 9.0 \\
\hline private fixed investment & 3.8 & 4.9 & 3.8 & 4.3 & 4.5 & 5.7 & 6.4 & 6.8 & 7.1 & 7.3 \\
\hline Foreign savings & 0.3 & 4.5 & 6.3 & 3.6 & 2.3 & 1.1 & 0.8 & 0.4 & 0.0 & -0.5 \\
\hline \multicolumn{11}{|l|}{ Central governunent budget } \\
\hline Total revenue and grants & 34.8 & 27.4 & 26.0 & 23.5 & 24.5 & 25.3 & 25.2 & 25.2 & 25.2 & 252 \\
\hline Total expenditure and net lending & 30.2 & 28.1 & 29.2 & 29.9 & 27.7 & 26.7 & 25.9 & 25.5 & 25.4 & 25.3 \\
\hline Capital expenditure & 4.7 & 4.7 & 4.2 & 5.3 & 5.7 & 5.8 & 6.3 & 6.7 & 7.2 & 7.6 \\
\hline (As a percent of total expenditure) & 15.7 & 16.9 & 14,4 & 17.6 & 20.6 & 21.7 & 24.2 & 26.3 & 28.2 & 30.0 \\
\hline Current expenditure & 25.4 & 23.3 & 25.0 & 24.7 & 22.0 & 20.9 & 19.6 & 18.8 & 18,2 & 17.7 \\
\hline Of which: interest payments & 3.5 & 2.7 & 2.7 & 2.6 & 2.9 & 3.0 & 2.9 & 2.9 & 2.8 & 2.7 \\
\hline Overalt balance & 4.6 & -0.6 & -3.2 & -6.5 & -3.2 & -1.4 & -0.7 & .0 .3 & -0.2 & -0.2 \\
\hline Underlying balance 2 & -3.9 & -1.2 & -3.2 & -6.5 & -5.1 & -1.4 & -0.7 & -0.3 & -0.2 & -0.2 \\
\hline Primary balance & 8.1 & 2.0 & -0.5 & -3.8 & -0.3 & 1.5 & 2.2 & 2.6 & 2.6 & 2.6 \\
\hline Debt outstanding & 39.8 & 37.0 & 40.9 & 43.8 & 44.7 & 43.9 & 43.7 & 42.7 & 41.6 & 40.4 \\
\hline \multicolumn{11}{|l|}{ Balance of payments } \\
\hline Exports, f.o.b. (percent change) & -24.1 & 25.8 & $-0,2$ & -8.8 & -3.4 & 9.7 & 5.4 & 6.9 & 7.3 & 7.4 \\
\hline Imports, f.o.b. (percent change) & -24.9 & 27.3 & -8.8 & -6.9 & 4.5 & 7.9 & 5.2 & 6.6 & 6.9 & 7.0 \\
\hline Trade balance & -11.6 & -13.5 & -11.1 & -10.7 & -13.0 & $-12,2$ & -12.3 & -12.4 & -12.5 & -12.5 \\
\hline Services, transfers and factor income (net) & 11.3 & 9.0 & 4.8 & 7.1 & 10.7 & 11.2 & 11.5 & 12.0 & 12.4 & 12.9 \\
\hline Current account balance & -0.3 & -4.5 & -6.3 & -3.6 & -2.3 & -1.1 & -0.8 & -0.4 & 0.0 & 0.5 \\
\hline Capital account balance & 4.7 & 4.7 & 6.4 & 4.7 & 1.3 & 2.7 & 3.4 & 3.3 & 3.3 & 3.3 \\
\hline Errors and omissions & -2.3 & 2.5 & 2.7 & -1.8 & 0.0 & 0.0 & 0.0 & 0.0 & 0.0 & 0.0 \\
\hline Overall balance & 2.0 & 2.7 & 2.8 & -0.8 & -1.0 & 1.6 & 2.6 & 2.9 & 3.3 & 3.8 \\
\hline \multicolumn{11}{|l|}{ Mernorandum items: } \\
\hline Gross official reserves (USS millions) & 385 & 421 & 410 & 366 & 350 & 378 & 426 & 480 & 545 & 624 \\
\hline (In months of imports) $3 /$ & 4.8 & 4.2 & 4.4 & 4.3 & 3.8 & 3.8 & 4.1 & 4.3 & 4.6 & 4.9 \\
\hline Medium- or long-term external debt & 13.6 & 14.1 & 14.7 & 13.4 & 13.3 & 13.6 & 14.7 & 15.6 & 16.4 & 17.2 \\
\hline Debt service (as a percent of exports) 4 / & 4.1 & 3.2 & 2.9 & 1.9 & 2.1 & 2.1 & 2.3 & 2.4 & 2.4 & 2.5 \\
\hline
\end{tabular}

Sources: Data provided by Fiji authorities; and Fund staff estimates.

1/ Defined as cument revenue less current expenditure. Note that budget revenue is classified into current and capital revenue, as is bud get expenditure.

$2 /$ Excludes National Bank of Fiji restructuring costs, and privatization receipts.

3/ Imports of goods, f.o.b., and nonfactor services.

4/ Exports of goods, f.o.b., and nonfactor services. 
FIJI: FUND RELATIONS

As of June 30,2002

\section{A. Financial Relations}

I. Membership Status: Joined: 05/28/71; Article VIII

II. General Resources Account:

Quota

Fund holdings of currency

SDR million

$\%$ Quota

70.30

100.0

Reserve position in Fund

55.30

78.7

15.00

21.3

III. SDR Department:

SDR million

$\%$ Allocation

6.96

100.0

Holdings

4.91

70.6

IV. Outstanding Purchases and Loans: None

V. Financial Arrangements: None

VI. Projected Obligations to Fund: None

\section{B. Nonfinancial Relations}

\section{Exchange Rate Arrangements}

Since April 1975, the exchange rate of the Fiji dollar has been linked to a basket of Fiji's five major trading-partner currencies: the U.S., Australian, and New Zealand dollars; the pound sterling (replaced by the Euro at the beginning of 2000); and the Japanese yen. The weights in the basket are based on a three-year moving average of Fiji's direction of trade, are reassessed annually, and are not publicly disclosed. Reserve Bank of Fiji (RBF) buying and selling rates for U.S. dollars are determined and communicated to commercial banks daily. The Fiji dollar was devalued by 20 percent against the basket on January 20,1998. Nominal and real effective rates have remained broadly stable in the period since then. The exchange rate was F\$2.11 per U.S. dollar on July 19, 2002.

Exchange and capital controls were tightened significantly on May 22, 2000, but have been eased on four subsequent occasions. There remain quantitative restrictions in Fiji dollars on offshore portfolio and direct investments by the Fiji National Provident Fund and other resident nonbank financial institutions, companies, and individuals, and payments for items ranging from merchandise imports to dividends to debt service are subject to case-by-case approval by the RBF when in excess of specified threshold amounts in Fiji dollars. 


\section{Last Article IV Consultation}

The 1998 Article IV consultation discussions were held in Suva during June 15-27, 1998. The consultation (SM/98/216 and SM/98/217) was completed by the Executive Board on September 14, 1998. The 2000 Article IV consultation was postponed as a result of domestic political instability. Fiji is on a 24-month cycle with the concurrence of the authorities.

\section{Technical Assistance from Headquarters}

FAD: Assistance on mineral taxation, May 1994. Assistance on corporate income tax and tax incentives reform, March-April 1995.

MAE: Long-term policy advisor with the Reserve Bank of Fiji, July 1993-November 1996. Assistance on monetary management, money and securities markets, and foreign exchange operations, September 1994. Assistance on bank supervision and monetary management, February 1996. Assistance on exchange rate arrangement and capital account liberalization, November 1997. Assistance on bank supervision, August 1998-August 1999. Assistance on insurance sector supervision, March 2002.

STA: Balance of payments and national accounts long-term expert, January 1994-February 1997. Balance of payments long-term expert, June 1997-June1999. Assistance on GDDS metadata development, July 1998. Multisector statistics advisor, October 1999-October 2002. Assistance on multisector statistics, January 2002.

X. Resident Representative: None. 


\section{FIJI: RELATIONS WITH THE \\ Pacific Financial Technical Assistance Centre ${ }^{1}$}

The Centre's assistance to Fiji since 1996 has included 24 advisory missions, especially with regard to public financial management and tax administration, often in conjunction with other technical assistance providers, and a large number of informal contacts. The Centre has also arranged for various government institutions in Fiji to regularly host for training officials on attachment from other Pacific island countries.

\section{Public Financial Management}

Recent advice from the Centre has concentrated on assessing the New Zealand-inspired Public Finance Management Act 1999 and the scope and format for achieving its principal objectives, with appropriate prioritization and sequencing of reform in light of limited capacity and skills, as well as on training needs. In addition, in 2002, the Centre conducted a full evaluation of public financial management against domestic needs and the key principles of the Code of Good Practices on Fiscal Transparency and recommended that top priority be given to strengthening internal controls.

\section{Tax Administration and Policy}

Following the introduction of a value added tax in July 1992, the Centre assisted the administration with several issues of its effective implementation, including the preparation of guidelines/handbooks and training in recovery procedures and audits. The Centre also complemented the large technical assistance programs of Australia and New Zealand on tax and customs reform, including the establishment of an Investigation and Intelligence Section.

\section{Financial Sector Regulation and Supervision}

The presence of the Centre in the Reserve Bank of Fiji building and the close contacts with RBF management and staff have made assistance to Fiji in this area a mostly informal matter, focused mainly on functions of the supervision department and on staffing and training needs. Moreover, RBF staff and the Centre have often worked closely together on staging regional events on banking regulation and supervision.

\section{Economic and Financial Statistics}

Initial assistance of the Centre in this area focused on technical issues related to the establishment of current and constant price national accounts data. More recently, at the authorities' request, the Centre assisted with the preparation of a comprehensive assessment of statistics operations in the country and the development of a multi-year action plan to strengthen both the organization and content of statistics.

\footnotetext{
${ }^{1}$ The Pacific Financial Technical Assistance Centre (PFTAC) in Suva, Fiji, is a multi-donor technical assistance institution, financed by the IMF, the UNDP, the AsDB, AusAID and NZODA, with the IMF as Executing Agency. The Centre's aim is to build skills and institutional capacity for effective economic and financial management that can be sustained at the national level. Member countries are: Cook Islands, Federated States of Micronesia, Fiji, Kiribati, Marshall Islands, Nauru, Niue, Palau, Papua New Guinea, Samoa, Solomon Islands, Tokelau, Tonga, Tuvalu, and Vanuatu.
} 


\section{FIJI: RELATIONS WITH THE WORLD BANK GROUP ${ }^{1}$ \\ (As of June 13, 2002)}

To date the World Bank has provided 13 loans totaling $\$ 143.3$ million (net of cancellations). There arc no Bank-supported lending projects under implementation or in the pipeline at present. There is a significant list of possible economic and sector work that has been identified by the authorities. The country office has offered to work with the authorities to expedite a review of these proposals. In addition, as part of the Bank's work on commodity risk, the Fiji sugar industry was identified as a possible case study for market-based approaches to commodity price risk management.

IFC has two venture loan investments in Fiji, $\$ 350,000$ in Solander (Pacific) Fiji Limited, and \$3.9 million in Outrigger Reef Resort. Solander continues to perform well, but Outrigger has been substantially impacted by the events of May 2000 .

The Foreign Investment Advisory Service is assisting the government in reviewing existing tax concessions, import duty concessions, and other incentives. An initial report has been prepared. A new pipeline of assistance is feasible through the Sydney-based South Pacific Project Facility:

\section{Foreign Investment Advisory Service}

An investment incentives overhaul was essentially completed in early 2000 . Assistance with implementation has occurred through the introduction of a Duty Suspension Scheme (DSS) for exporters in January 2002. Further assistance with the fine-tuning of the DSS is anticipated.

\section{Global Development Learning Network}

Initial conceptual and technical discussions took place on establishing a distance learning center within the University of the South Pacific (USP) in June 2000. USP is currently discussing possible financing and content arrangements with the Bank and with AusAID.

\begin{tabular}{|lrrrrrrrr|}
\hline \multicolumn{7}{|c|}{$\begin{array}{c}\text { Fiji: World Bank Group Financial Operations } \\
\text { (In millions of U.S. dollars) }\end{array}$} \\
\hline & $\mathbf{1 9 9 5}$ & $\mathbf{1 9 9 6}$ & $\mathbf{1 9 9 7}$ & $\mathbf{1 9 9 8}$ & $\mathbf{1 9 9 9}$ & $\mathbf{2 0 0 0}$ & $\mathbf{2 0 0 1}$ \\
\hline Loan Approvals & 39.3 & 0 & 0 & 0 & 0 & 0 & 0 \\
Loan Disbursements & 17.7 & 6.6 & 4.2 & 2.6 & 3.2 & 1 & 0 \\
Balance Undisbursed & 21.6 & 15 & 10.8 & 8.2 & 5 & 4 & 0 \\
\hline 1/ Bank calendar year. & & & & & & & \\
\hline
\end{tabular}

\footnotetext{
${ }^{1}$ Prepared by World Bank staff.
} 


\section{FIJI: RELATIONS WITH THE ASIAN DEVELOPMENT BANK (As of May 28, 2002)}

To date, the Asian Development Bank (AsDB) has approved 13 loans totaling \$161.1 million. The only ongoing loan is for the Third Road Upgrading Project, at \$40 million, approved in August 1997. Project implementation progress is satisfactory. The Fiji Ports Development Project loan, at $\$ 16.8$ million, was approved in February 2002. The Fiji government has provided sufficient counterpart funding for AsDB-financed projects. However, with migration of skilled staff, the availability of high caliber staff to implement programs is problematic, affecting the absorptive capacity of various government agencies.

The AsDB has approved 62 TA projects, totaling \$18.3 million, since 1970. There are 8 advisory TA initiatives ongoing, for public enterprise reforms, public debt management, capital markets development, road-sector reform and safety improvement, a women's action plan, the preparation of a medium-term development plan, the Native Land Trust Board's land boundaries mapping, and a review of the Fiji Development Bank. Most TA is being implemented satisfactorily. The AsDB continues to be involved in helping to improve the policy framework in agriculture, infrastructure, and the environment.

As a result of the coup in 2000 , no country programming was undertaken in 2001 , but two country consultation missions were undertaken. No TA was approved in 2001, but in October it was agreed to resume all suspended TA. Initiatives agreed for 2002 comprise project preparatory TA for alternative livelihoods and rural electrification, and advisory TA for sugarsector restructuring and for institutional strengthening attached to a proposed water supply and sanitation project (being processed for approval in 2002). For 2003, project preparatory TA has been identified for airports rehabilitation and tourism development, and advisory TA for IT policy and legal framework and for governance strengthening, including the implementation of the Financial Management Act and capacity building in key government ministries. The TA program, estimated at about $\$ 1.9$ million in total, will next be reviewed during the 2003 country programming mission.

\section{Monitoring and evaluation}

There is no AsDB resident mission in Fiji, and project implementation is monitored by review missions from AsDB headquarters. Generally, Fiji has complied with project loan covenants, including submission of regular progress and audit reports. However, a few major covenants pertaining to road-sector policies are yet to be complied with due to pending reform of the Public Works Department's road section.

\section{Lending level proposed}

AsDB lending to Fiji in 2002 is estimated at $\$ 50$ million. Based on the strong project pipeline and the availability of new LIBOR-based loan products, proposed lending is estimated at \$4050 million annually for 2002-2005. Grant cofinancing and opportunities for commercial cofinancing and guarantees will be sought where appropriate. Currently, there are good 
prospects for cofinancing from domestic banks, as was done for the Fiji Ports Development Project.

\section{TA program}

The TA pipeline is designed to support the main areas of emphasis identified in the country strategy and program including project preparation, institutional strengthening, and capacity building for good governance. The TA program is envisaged to be about \$1.5-2 million annually, with at least 50 percent for project preparation. 
FIJI: SOCIAL AND DEMOGRAPHIC INDICATORS

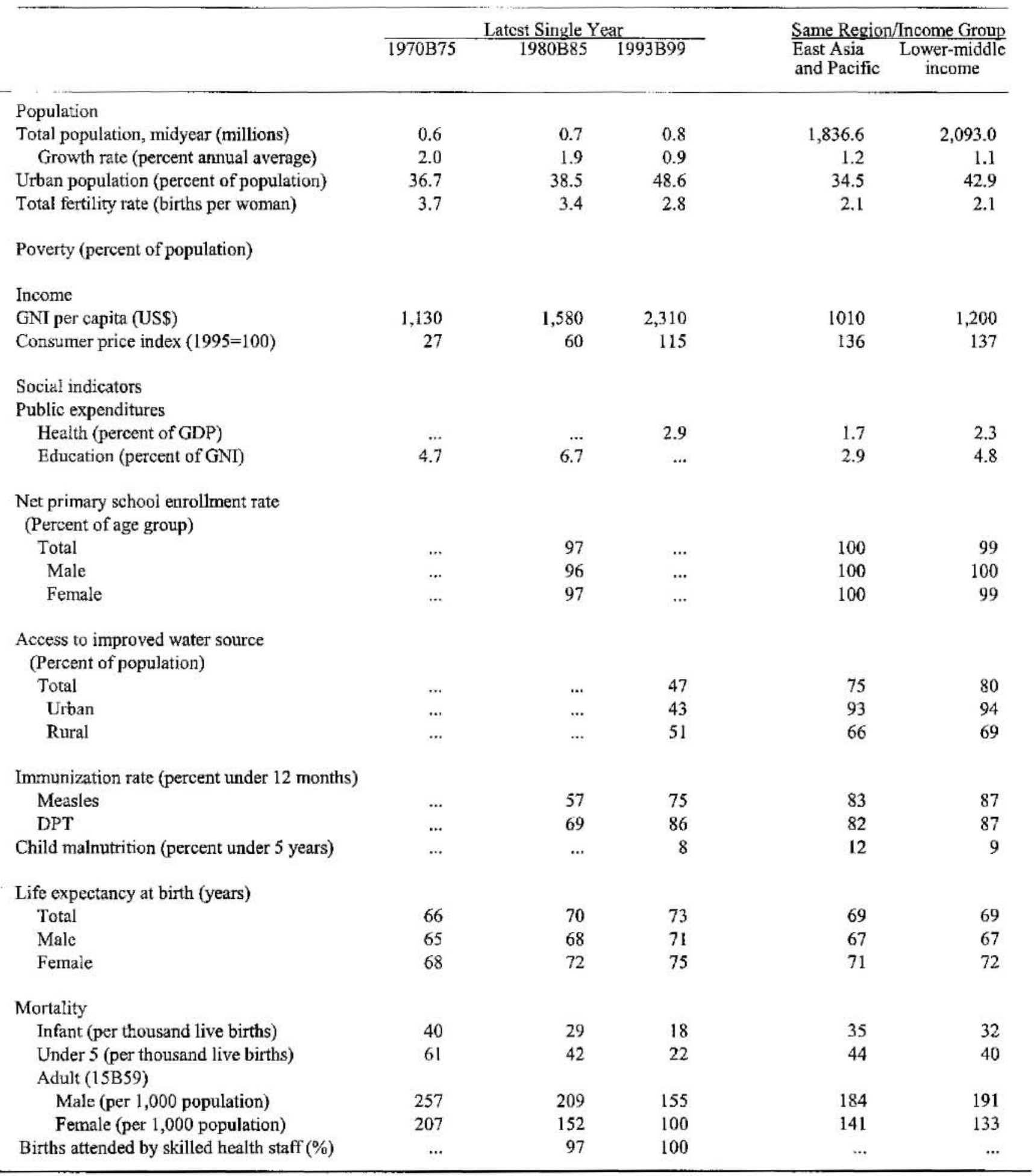

Source: World Development Indicators, World Bank.

Note: 0 or 0.0 means zero or less than half the unit shown. Net enrollment ratios exceeding 100 indicate discrepancies between the estimates of school-age population and reported enrollment data. Latest year for access to improved water source data is 2000. 


\section{FIJI: STATISTICAL IsSUES}

The economic database in Fiji is reasonably solid, owing in part to the considerable TA provided by the Fund in recent years, mainly through the PFTAC in Suva. The authorities are fully cooperative in providing data to the Fund in a timely manner. Although weaknesses persist (see below), the authorities have been trying to improve all these aspects. A major problem recently has been the loss of skilled staff through emigration.

The RBF publishes the Annual Report, the Quarterly Review, the Monthly Economic Bulletin, and the monthly News Review. The Fiji Bureau of Statistics (BoS) publishes a quarterly Current Economic Statistics and a monthly Statistical News. Each year, the Ministry of Finance and National Planning (MoF) issues the Budget Address and the Supplement to the Budget Address. All of these publications are received by APD on a regular basis.

Fiji's formal participation in the GDDS commenced on May 9, 2000, marked by the posting of Fiji's metadata to the IMF's Dissemination Standards Bulletin Board. Fiji has maintained its commitment to use the GDDS as a framework for statistical development, and to update the GDDS metadata at least once per year.

\section{National Accounts}

The BoS compiles production GDP at factor cost (i.e. net of indirect taxes and subsidies) at current and constant prices. The current price estimates are derived by extrapolation of 1989 value added by sector using output indicators. This data is available up to 2001. The BoS plans to rebase the current national accounts series to 1995 . With assistance from the PFTAC, estimates of expenditure GDP at current prices have been compiled and are available up to 2000. The BoS is conducting a new Household Expenditure and Income Survey (HEIS) based on the 1993 System of National Accounts (1993 SNA) as a conceptual framework, with a target completion date of December 2002. The HEIS will also be used to update the CPI weights from the current 1993 base.

\section{Government Finance Statistics}

Until 1996, Fiji was a regular reporter of data for publication in the Government Finance Statistics (GFS) Yearbook. There were however, some inconsistencies between the GFS data and fiscal data provided to APD, especially in the areas of nontax revenue, wages and salaries, other purchases of goods and services, and subsidies and transfers. The STA database included data on central government budgetary operations through 1996. Government debt data reported by the authorities for the years 1987 through 1990 have not been included in the database, owing to methodological problems. Public debt data remain weak. The MoF is considering the adoption of the new methodology in the IMF Government Finance Statistics Manual (2001). Monthly and quarterly GFS data last reported refer to 1999. 


\section{Monetary Statistics}

Statistics on the monetary authorities and the deposit money banks are comprehensive and are provided to STA on a regular and timely basis. Data on nonbank financial institutions, including the Fiji National Provident Fund, are less regular, timely, and reliable. With such institutions representing a large part of the domestic financial system, the unavailability of a consolidated financial survey forms an important obstacle to economic and financial analysis. The RBF plans to implement the methodology of the IMF Monetary and Financial Statistics Manual (2000).

\section{Balance of Payments}

In the balance of payments area, the lack of timely merchandise trade data obtained from customs documentation is a major problem. The Fiji Inland Revenue and Customs Authority has adopted UNCTAD's Automated System of Customs Data (ASYCUDA) system for processing merchandise through customs. However, ASYCUDA has made it more difficult to detect the occasional errors in breaking down volumes and prices of exports and imports. Additional problems, particularly in the measurement of external debt, derive from the absence of a consistent framework and insufficient coordination between the RBF, the BoS, and the MoF. With assistance from PFTAC, the BoS has begun to report annual balance of payments data according to the IMF Balance of Payments Manual (fifth edition) format. However, the data are not timely and the latest data reported for publication by the Fund refer to1999 and were received in October 2000. 
Fiji: Core Statistical Indicators

(As of June 19, 2002)

\begin{tabular}{|c|c|c|c|c|c|c|c|c|c|c|c|c|}
\hline & $\begin{array}{c}\text { Exchange } \\
\text { Rates }\end{array}$ & $\begin{array}{l}\text { International } \\
\text { Reserves }\end{array}$ & $\begin{array}{c}\text { Central } \\
\text { Bank } \\
\text { Balance } \\
\text { Sheet }\end{array}$ & $\begin{array}{c}\text { Reserve/ } \\
\text { Base } \\
\text { Moncy }\end{array}$ & $\begin{array}{l}\text { Broad } \\
\text { Money }\end{array}$ & $\begin{array}{l}\text { Interest } \\
\text { Rates }\end{array}$ & $\begin{array}{l}\text { Consumer } \\
\text { Price } \\
\text { Index }\end{array}$ & $\begin{array}{l}\text { Exports/ } \\
\text { Imports }\end{array}$ & $\begin{array}{l}\text { Current } \\
\text { Account } \\
\text { Balance }\end{array}$ & $\begin{array}{c}\text { Overall } \\
\text { Government } \\
\text { Balance }\end{array}$ & $\begin{array}{l}\text { GDP/ } \\
\text { GNP }\end{array}$ & $\begin{array}{c}\text { External } \\
\text { Debt/ } \\
\text { Debt } \\
\text { Service }\end{array}$ \\
\hline $\begin{array}{l}\text { Date of latest } \\
\text { observation }\end{array}$ & $05 / 02$ & $04 / 02$ & $04 / 02$ & $04 / 02$ & $04 / 02$ & $05 / 02$ & $03 / 02$ & $\mathrm{Q} 3 / 01$ & $\mathrm{Q} 4 / 00$ & $\mathrm{Q} 3 / 01$ & 2001 & Q2/02 \\
\hline Date received & $06 / 02$ & $06 / 02$ & $06 / 02$ & $06 / 02$ & $06 / 02$ & $06 / 02$ & $05 / 02$ & $03 / 02$ & $03 / 02$ & $03 / 02$ & $03 / 02$ & $03 / 02$ \\
\hline Frequency of data & $\mathbf{M}$ & M & M & M & M & M & M & Q & $Q$ & Q & A & $Q$ \\
\hline $\begin{array}{l}\text { Frequency of } \\
\text { Reporting }\end{array}$ & M & $\mathrm{M}$ & M & M & M & M & M & Q & $Q$ & $\mathrm{Q}$ & A & $Q$ \\
\hline Source of update & $\begin{array}{c}\text { Reserve } \\
\text { Bank of } \\
\text { Fiji }\end{array}$ & $\begin{array}{c}\text { Reserve } \\
\text { Bank of } \\
\text { Fiji }\end{array}$ & $\begin{array}{c}\text { Reserve } \\
\text { Bank of } \\
\text { Fiji }\end{array}$ & $\begin{array}{c}\text { Reserve } \\
\text { Bank of } \\
\text { Fiji }\end{array}$ & $\begin{array}{c}\text { Reserve } \\
\text { Bank of } \\
\text { Fiji }\end{array}$ & $\begin{array}{c}\text { Reserve } \\
\text { Bank of } \\
\text { Fiji } \\
\end{array}$ & $\begin{array}{l}\text { Bureau of } \\
\text { Statistics }\end{array}$ & $\begin{array}{c}\text { Reserve } \\
\text { Bank of } \\
\text { Fiji }\end{array}$ & $\begin{array}{c}\text { Reserve } \\
\text { Bank of } \\
\text { Fiji }\end{array}$ & $\begin{array}{c}\text { Reserve } \\
\text { Bank of } \\
\text { Fiji }\end{array}$ & $\begin{array}{c}\text { Reserve } \\
\text { Bank of } \\
\text { Fiji }\end{array}$ & $\begin{array}{c}\text { Reserve } \\
\text { Bank of } \\
\text { Fiji }\end{array}$ \\
\hline Mode of reporting & $\begin{array}{c}\text { E-mail } \\
\text { (IFS report } \\
\text { forms) }\end{array}$ & $\begin{array}{c}\text { E-mail } \\
\text { (IFS report } \\
\text { forms) }\end{array}$ & $\begin{array}{l}\text { E-mail } \\
\text { (IFS } \\
\text { report } \\
\text { forms) }\end{array}$ & $\begin{array}{c}\text { E-mail } \\
\text { (IFS } \\
\text { report } \\
\text { forms) }\end{array}$ & $\begin{array}{l}\text { E-mail } \\
\text { (IFS } \\
\text { report } \\
\text { forms) }\end{array}$ & $\begin{array}{l}\text { E-mail } \\
\text { (IFS } \\
\text { report } \\
\text { forms) }\end{array}$ & $\begin{array}{c}\text { (Mail) } \\
\text { Statistical } \\
\text { News }\end{array}$ & $\begin{array}{l}\text { (Mail) } \\
\text { Quarterly } \\
\text { Bulletin }\end{array}$ & $\begin{array}{c}\text { (Mail) } \\
\text { Quarterly } \\
\text { Bulletin }\end{array}$ & $\begin{array}{l}\text { (Mail) } \\
\text { Quarterly } \\
\text { Bulletin }\end{array}$ & $\begin{array}{l}\text { (Mail) } \\
\text { Quarterly } \\
\text { Bulletin }\end{array}$ & $\begin{array}{c}\text { (Mail) } \\
\text { Quarterly } \\
\text { Bulletin }\end{array}$ \\
\hline Confidentiality & None & None & None & None & None & None & None & None & None & None & None & None \\
\hline $\begin{array}{l}\text { Frcquency of } \\
\text { publication }\end{array}$ & M & M & M & M & M & M & M & Q & Q & $\mathrm{Q}$ & Q & $Q$ \\
\hline
\end{tabular}




\section{INTERNATIONAL MONETARY FUND}

\section{Public Information Notice}

Public Information Notice (PIN) No.01/101 FOR IMMEDIATE RELEASE

September 12, 2002
International Monetary Fund $70019^{\text {th }}$ Street, NW

Washington, D. C. 20431 USA

\section{IMF Concludes 2002 Article IV Consultation with Fiji}

On August 9, 2002, the Executive Board of the International Monetary Fund (IMF) concluded the Article IV consultation with Fiji. ${ }^{1}$

\section{Background}

In May 2000, political instability led to the overthrow of the elected government. In response, several governments and international donor agencies suspended their development programs in Fiji. Australian and New Zealand trade unions also adopted measures interfering with the importation of Fijian goods. Elections were held in September 2001, and led to a full resumption of development programs and to the normalization of Fiji's international relations. The domestic political situation has also become more settled, although court challenges have continued against the government.

Following the political crisis, Fiji experienced sharp declines in tourism earnings, while external sanctions adversely affected investment and textile exports. As a result, GDP fell $2 \frac{3 / 4}{4}$ percent in 2000 , and the current account deficit widened to $61 / 2$ percent of GDP. Financial stability and the basket peg of the Fiji dollar were maintained through tightening of domestic monetary policy and exchange controls, together with government spending cuts to offset the impact of weaker growth on the fiscal deficit. As the political and security situation began to normalize, and financial market pressures dissipated, monetary and fiscal policies were eased.

\footnotetext{
' Under Article IV of the IMF's Articles of Agreement, the IMF holds bilateral discussions with members, usually every year. A staff team visits the country, collects economic and financial information, and discusses with officials the country's economic developments and policies. On return to headquarters, the staff prepares a report, which forms the basis for discussion by the Executive Board. At the conclusion of the discussion, the Managing Director, as Chairman of the Board, summarizes the views of Executive Directors, and this summary is transmitted to the country's authorities. This PIN summarizes the views of the Executive Board as expressed during the August 9, 2002 Executive Board discussion based on the staff report.
} 
Economic recovery began in 2001 , with real GDP rising by $33 / 4$ percent, largely owing to a pick up in the tourism and garment sectors and the impact of fiscal stimulus measures boosting the fiscal deficit to over 6 percent of GDP. Inflation remained low, reflecting weak domestic demand pressures and stability in the exchange rate, and the current account deficit narrowed to $3 \frac{1}{2}$ percent of GDP in 2001 as tourism earnings recovered.

Growth is projected to rise to the 4 to 6 percent range in 2002-2003, partly reflecting further strengthening of the tourism sector and the resumption of development assistance projects. Despite the pickup in growth, fiscal policy has remained expansionary, and the underlying fiscal deficit could reach 8 percent of GDP in 2002. The Government has announced its intention to pursue fiscal consolidation over the medium term. Inflation pressures remain modest and the current account deficit is expected to narrow further. Despite the recovery, some important areas of economic weakness remain; in particular, the sugar industry has continued to contract as land tenure problems remain unresolved. Private investment-including foreign direct investment ( $\mathrm{FDI}$ ) - also remains very weak, reflecting uncertainties of borrowers and lenders regarding the longer-term political and economic outlook. Foreign reserves remain comfortable, at 3.7 months of goods and non-factor services, and the exchange rate remains stable.

\section{Executive Board Assessment}

Executive Directors commended the Fiji authorities for their success in containing the macroeconomic consequences of the political events of May 2000. Building on these prompt policy actions, Fiji is now experiencing an increasingly broad-based economic expansion, accompanied by low inflation.

The key economic challenge ahead will be to raise the sustainable rate of growth, supported by a durable expansion of private sector investment, while preserving macroeconomic stability in a climate of political stability. With economic recovery well under way, Directors advised the authorities to shift the focus of policy from boosting economic activity to laying the foundations for a sustained improvement in economic performance. At the heart of this strengthened policy framework should be an early and sustained fiscal consolidation effort to correct the large public sector deficit, together with an intensification of structural reforms, including a well-sequenced withdrawal of widespread administrative controls.

In light of this, Directors supported the authorities' medium-term fiscal strategy of reducing the government debt-to-GDP ratio to 40 percent, while raising substantialiy the share of public spending on investment. They recommended that the authorities take early action to reduce the fiscal deficit significantly, working toward a sufficient primary surplus to achieve the consolidation target, and using privatization proceeds to reduce the debt. This will require expenditure restraint, including on wage costs, as well as improved tax collection, while an increase in the value-added tax rate should be considered to help finance the desired increase in public investment spending.

Directors considered that, with inflation pressures weak, very slow money and credit growth, and an adequate level of official reserves, monetary policy should remain supportive of 
economic activity. The peg of the Fiji dollar to a basket of trading partner currencies continues to play its well-established role in underpinning Fiji's price performance and financial stability, and Directors supported its continuation. At the same time, somewhat greater exchange rate flexibility, supported by appropriate fiscal and monetary policies, will facilitate the removal of exchange controls and help provide a buffer against external shocks, and the authorities' intention to move carefully in that direction is welcome.

Fiji maintains a wide range of exchange controls, including restrictions on current account transactions, which are unhelpful to Fiji's efforts to attract increased foreign investment. Directors recommended that the authorities set a clear timetable for eliminating the restrictions on current payments, while embarking on a wider effort to liberalize exchange controls.

Fiji's banking system appears to be sound, and is supported by adequate regulations and supervision. Directors welcomed the authorities' plans for expanding the central bank's supervisory power to nonbank financial institutions, as well as their intention to participate in the Financial Sector Assessment Program. They encouraged the authorities to continue and strengthen their efforts to combat money laundering and the financing of terrorism.

Directors noted that an acceleration of structural reforms will be key for raising Fiji's sustainable growth rate, while helping to achieve fiscal consolidation. They looked forward to the early implementation of the public sector management and financial management reforms, which will strengthen transparency and accountability as well as improve prioritization and efficiency. Other priorities are the reduction of administrative obstacles to investment, the dismantling of price controls, and the elimination of distortionary import licenses and quotas. The authorities are encouraged to proceed with further privatizations in the period ahead. Directors also stressed the need for comprehensive restructuring of the sugar industry, noting, in this connection, the challenge facing the authorities to achieve a resolution of the sensitive land lease issue.

Public Information Notices (PINs) are issued, (i) at the request of a member country, following the conclusion of the Article IV consultation for countries seeking to make known the views of the IMF to the public. This action is intended to strengthen IMF surveillance over the economic policies of member countries by increasing the transparency of the IMF's assessment of these policies; and (ii) following policy discussions in the Executive Board at the decision of the Board. 
Fiji: Selected Economic and Financial Indicators

\begin{tabular}{|c|c|c|c|c|c|c|}
\hline & 1997 & 1998 & 1999 & 2000 & 2001 & $\begin{array}{r}2002 \\
\text { Est. }\end{array}$ \\
\hline & \multicolumn{6}{|c|}{ (Percentage change) } \\
\hline \multicolumn{7}{|l|}{ Output and prices } \\
\hline Real GDP (at constant factor cost) & -0.9 & 1.5 & 9.6 & -2.8 & 3.8 & 4.4 \\
\hline Sugar cane production & -23.5 & -26.3 & 41.6 & -7.5 & -7.1 & -4.3 \\
\hline Tourist arrivals & 5.9 & 3.3 & 10.4 & -28.3 & 18.3 & 8.6 \\
\hline Consumer prices (average) & 3.4 & 5.9 & 2.0 & 1.1 & 4.3 & 2.4 \\
\hline Gross national savings (percent of GDP) & 13.0 & 15.4 & 8.0 & 5.6 & 9.1 & 10.9 \\
\hline Gross domestic investment (percent of GDP) & 11.3 & 15.7 & 12.1 & 12.0 & 12.7 & 13.8 \\
\hline \multirow[t]{2}{*}{ Foreign savings (percent of GDP) } & -1.6 & 0.3 & 4.0 & 6.4 & 3.6 & 2.9 \\
\hline & \multicolumn{6}{|c|}{ (Percent of GDP) } \\
\hline \multicolumn{7}{|l|}{ Central government budget } \\
\hline Revenue and grants & 26.3 & 34.8 & 27.4 & 25.9 & 23.5 & 24.5 \\
\hline Total expenditure $1 /$ & 32.9 & 30.2 & 28.1 & 29.1 & 30.0 & 30.6 \\
\hline Of which: Capital $1 /$ & 8.7 & 4.7 & 4.7 & 4.2 & 5.3 & 6.9 \\
\hline Overall balance & -6.6 & 4.6 & -0.6 & -3.2 & -6.5 & -6.1 \\
\hline Underlying balance $1 /$ & -2.4 & -3.9 & -1.2 & -3.2 & -6.5 & -8.0 \\
\hline \multirow[t]{2}{*}{ Public debt outstanding } & 44.3 & 39.8 & 37.0 & 40.8 & 43.8 & 47.4 \\
\hline & \multicolumn{6}{|c|}{ (Percentage change) } \\
\hline \multicolumn{7}{|l|}{ Money and credit $2 /$} \\
\hline Domestic credit & -10.2 & 3.8 & 4.3 & 5.7 & -2.5 & -1.4 \\
\hline Private sector & -13.0 & 5.7 & 6.6 & 0.2 & -5.6 & -1.9 \\
\hline Broad money (M2) & -8.7 & -0.3 & 14.2 & -2.1 & -3.1 & 0.5 \\
\hline \multicolumn{7}{|l|}{ Balance of payments } \\
\hline \multicolumn{7}{|l|}{ Current account balance } \\
\hline (In percent of GDP) & 1.6 & -0.3 & -4.0 & -6.4 & -3.6 & -2.9 \\
\hline \multicolumn{7}{|l|}{ Gross official reserves } \\
\hline (In millions of U.S. dollars; end of period) $2 /$ & 361 & 386 & 429 & 410 & 367 & 336 \\
\hline (In months of imports of goods and services) & 3.5 & 4.8 & 4.3 & 4.4 & 4.3 & 3.6 \\
\hline \multicolumn{7}{|l|}{ External debt } \\
\hline (In millions of U.S. dollars.; end of period) $3 /$ & 227 & 225 & 261 & 242 & 225 & 253 \\
\hline (In percent of GDP) & 10.7 & 13.6 & 14.0 & 14.7 & 13.4 & 12.7 \\
\hline \multicolumn{7}{|l|}{ Debt service } \\
\hline (In percent of exports of goods and services) & 2.7 & 4.1 & 3.2 & 3.0 & 2.0 & 2.0 \\
\hline Real effective rate (average) $4 /$ & 112.2 & 93.0 & 93.5 & 92.0 & 92.3 & 92.8 \\
\hline Exchange Rate (F\$ per US\$; end of period) $5 /$ & 1.55 & 1.99 & 1.97 & 2.19 & 2.31 & 2.13 \\
\hline
\end{tabular}

Sources: Data provided by the authorities; and Fund staff estimates.

1/ Excludes National Bank of Fiji restructuring costs, and privatization receipts.

2/ Figure for 2002 is for end-May. 
3/ Medium- and long-term debt.

4/ IMF, Information Notice System Index, 1999=100. Figure for 2002 is for January-May. $5 /$ Figure for 2002 is for end-July. 


\section{Statement by Dono Iskandar Djojosubroto, Executive Director for Fiji August 9, 2002}

\section{Recent Economic Developments}

Fiji's economy rebounded in 2001 with a growth of 3.8 percent after experiencing a negative growth of 2.8 percent in 2000 largely due to the political crisis. The turnaround was due to robust growth in the clothing and footwear sector and quick recovery in the tourism industry.

The economic outlook for 2002 is encouraging, with GDP forecast to grow by 4.4 percent, supported by positive developments in all major sectors of the economy, except the sugar industry. Following the recovery in 2001, the tourism sector has continued to show good performance with a higher than expected number of visitors. In view of expected extraction of high quality ore as well as the recent general improvement in international gold prices, the prospects for the mining sector continue to remain optimistic. Garment production rose in 2001 and is expected to pick up again this year, particularly with the delivery of large consignments to the US market. In addition, production for the Australian market remains buoyant, boosted by favorable economic conditions in Australia. Copra production is also expected to increase, supported by the prevailing high mill gate price. Consequently, the economy is expected to grow by 5.9 percent in 2003 , boosted by higher investments and tourism earnings related to Fiji's hosting of the South Pacific Games.

Inflation in Fiji has remained low, and generally well below the Reserve Bank's implicit target range of 3-5 percent. CPI inflation moderated further to 2.3 percent at end 2001 and to 1.2 percent in March 2002. The low and stable inflation largely reflected the low inflation rates in its major trading partners. As the domestic and foreign price pressures are anticipated to remain weak, the 2002 year-end inflation is projected at 2.5 percent.

Mainly as a result of a timely policy response by the Fijian authorities, the external sector continued to hold up well in 2001. Despite a higher merchandise trade deficit largely reflecting lower demand for Fiji's exports and a rise in imports of capital goods, strong recovery in tourism income and improved private transfers have narrowed the current account deficit to 3.6 percent of GDP in 2001. At end March 2002, gross foreign reserves remained at a comfortable level at about $\$ 786$ million, sufficient to cover 3.7 months of imports of goods and non-factor services. 


\section{Fiscal Policy}

During 2000, my Fijian authorities implemented corrective fiscal policy measures to contain the adverse economic consequences of the political crisis. A mini-budget, introduced in July 2000 , with a tough line on expenditure reducing measures, had contained the fiscal deficit at 3.2 percent of GDP in 2000 . However, despite a substantial improvement in VAT collection, the Government's efforts to stimulate the economy through fiscal incentives and higher expenditures resulted in a higher budget deficit of 6.5 percent of GDP in 2001 .

The 2002 budget proposed an expansionary policy with more resources allocated to capital spending, aimed at supporting growth. This reflects the Government's commitment to a more active role in rebuilding the economy, with greater emphasis on addressing basic needs; improving economic efficiency and competitiveness; and reforming the civil service, public enterprises and public financial management. However, in view of the shortfall in tax revenue and the problem of tax arrears, my Fijian authorities are improving tax compliance and the collection of tax arrears by strengthening its institutional capacity through upgrading the tax information system, recruiting additional staff and providing them with the necessary training and equipment. The expected receipts from the privatization program will also reduce the pressure on the budget deficit.

My Fijian authorities have taken note of staff's recommendation to take immediate action to cut the fiscal deficit to around 3 percent of GDP in 2002 through a combination of cuts in wage cost and reducing capital expenditures. They agree that there is indeed a need for fiscal consolidation, but they are of the view that the economic recovery has to be firmly in place before any significant additional measures can be introduced. They also agree with staff that it is important to restore fiscal sustainability and to achieve the medium-term target of debt/GDP ratio at 40 percent.

\section{Monetary and Exchange Rate Policy}

The easy monetary policy stance, adopted in 1997, was continued in 2000 . However, following the coup in May 2000, the Reserve Bank of Fiji tightened its monetary policy through a combination of raising interest rate, imposing ceiling on credit to the private sector and existing exchange controls procedures were tightened, in order to prevent excessive capital outflow and to minimize pressure on the Fijian dollar. No new current account restrictions were introduced. In September of the same year, against a backdrop of a return to normalcy in the political and security situation, and a favorable assessment of economic conditions, monetary policy was eased by cutting interest rates progressively, removing the credit ceiling on commercial banks' lending and the exchange controls procedures were relaxed. The accommodative stance of monetary policy was continued in 2001 to stimulate demand and support economic recovery. To support the export sector, commercial banks were required, with effect from August 1, 2001, to lend a minimum of 5 percent of their average deposits to eligible exporters and data collected to date shows that commercial banks' lending to this sector far exceeded this ratio. The lending rate of the existing Export Finance Facility was also reduced from 3.0 to 2.0 percent. 
Since September 2000, the RBF has progressively relaxed exchange controls, including the re-introduction of the off-shore investment facility, re-delegation of certain exchange control approvals to commercial banks and authorized foreign exchange dealers, and partial reinstatement of the forward foreign exchange facility. The authorities are committed to further liberalizing exchange controls but they are mindful that it has to be carried out cautiously.

The long-established peg of the Fijian dollar to a basket of currencies of the major trading partners has served the economy well in providing an anchor for inflation and inflationary expectations. With the devaluation of about 20 percent in January 1998, the Fijian dollar has remained competitive. Against this background, my Fijian authorities have indicated their intention to retain the currency peg and to move cautiously to introducing a more flexible exchange rate in line with the recommendation of the MAE technical assistance mission.

\section{Financial Sector}

The Reserve Bank of Fiji is responsible for supervising all licensed financial institutions, including banks, credit institutions, foreign exchange dealers and insurance companies licensed in Fiji. The share of non-performing loans for banks has fallen to 6.4 percent in 2001 from 7.0 percent in 2000 . In the case of credit institutions, NPL continued to remain high, increasing from 11.9 percent in 2000 to 17.6 percent in 2001 .

As reported by staff, the banking sector is essentially healthy and the RBF's regulatory and supervisory role is adequate and effective. Fiji's financial sector is dominated by five foreign banks and the Fiji National Provident Fund (FNPF). Assets of the FNPF continued to grow in the past two years, unlike the other financial institutions. Of the total gross assets of the financial system, the non-bank financial institutions (NBFIs), including the FNPF, accounts for around 53 percent, while the other financial institutions accounts for around 47 percent. For these reasons, and taking into account the RBF's strong reputation and its staff's capability, the authorities plan to extend the RBF's supervisory coverage to the NBFIs, starting with the FNPF and the Fiji Development Bank.

The Reserve Bank has carried out an internal assessment of Fiji's banking supervisory regime for compliance with the minimum standards of the Basle Committee's Core Principle on banking supervision. Fiji has recently agreed to participate in the joint IMF-World Bank Financial Sector Assessment Program - the project is expected to commence in the latter part of 2003.

\section{Measures on AML/CFT}

The authorities have been working on the implementation and enforcement of the anti-money laundering law in Fiji. The Anti-Money Laundering Officials Committee, chaired by the Permanent Secretary of the Ministry of Justice, is currently reviewing the draft legislation to establish a Financial Intelligence Unit (FIU) under the Proceeds of Crime Act. It is expected that the necessary legislation to establish the FIU will be finalized by 
September 2002. Fiji is a member of the Asia Pacific Group on Money Laundering (APG), and a mutual evaluation exercise was conducted by the APG in mid-February 2002 . The findings indicate that Fiji is generally compliant with the regional and international antimoney laundering standards. My Fijian authorities have received the report and are working on measures and systems that may require further strengthening.

\section{Structural Measures}

\section{Financial Management Reform}

In the 2002 budget, the government announced its plan to support the implementation of a performance management system in the civil service, and to coordinate its implementation with financial management reform. To enhance fiscal transparency, which is an essential element of the financial management reform, the authorities indicated their intention: to strengthen the financial management information system; to revisit the 1999 Public Financial Management Act with a view to ensuring greater accountability; to adopt the IMF standard of fiscal transparency; and to reintroduce official rating on Fiji by an international rating agency. The authorities are also in agreement with staff that an interim monitoring arrangement should be put in place to improve financial control as the first phase of the financial management reform rescheduled for completion by mid- 2003 .

\section{Privatization issue}

During 2001 and 2002, a portion of the Government's shareholdings in the Amalgamated Telecom Holdings Ltd. (ATH) was sold to Fijian nationals and the FNPF. The FNPF now owns more than 50 percent of the ATH. The planned sale of 20 percent of the Government's shares in the Colonial National Bank (CNB) to Fijian nationals, Provisional Councils and the FNPF was postponed as a proposal by a foreign bank to buy 49 percent of the Government's share in the CNB at an attractive price was submitted to the Cabinet for consideration.

My Fijian authorities indicated that there are no immediate plans for further privatization beyond the planned sale of the Government's share in the CNB, and that they are focusing their efforts on the improvement of management and commercial operation of existing entities.

\section{Restructuring of Sugar Industry}

Sugar production has been declining since its peak in 1994, owing to a number of problems, including the land lease issue, low cane supply to the mills, and transportation and mill inefficiencies. The authorities are fully aware that if these problems are not resolved, the country is likely to face a number of challenges, in particular, lower growth, higher unemployment and a large scale migration of the unemployed rural population that will create additional strains on urban infrastructure and the social fabric. A proposal for restructuring the industry is under discussion and the good will and effective cooperation of the major players are crucial for success. 


\section{Improving Climate for Foreign Direct Investment}

My Fijian authorities acknowledge that simplification of the FDI approval process and removal of the barriers deterring foreign investment are necessary to attract foreign direct investment. Prompt action has been taken by the Ministry of Commerce, Business Development and Investment. They have employed a consultant to review the approval process, and a review of the Foreign Investment Act is being initiated.

\section{Statistical Issue}

On the statistical issue, my Fijian authorities have committed to continue their efforts to further improving the statistical data in the areas of trade and external debt and expenditure GDP, as well as the coverage of the monetary statistics. Fiji also participates in the General Data Dissemination System.

\section{Medium-Term Fiscal Strategy}

My Fijian authorities have adopted a medium-term fiscal strategy aimed at achieving a medium-term target of 40 percent for the central government debt/GDP ratio and raising the target share of government expenditure on investment to 30 percent. They have also indicated that staff's proposal to increase the VAT rate to 12 percent may be considered as an option to increase revenue in the 2003 budget.

\section{Conclusion}

In conclusion, my authorities are grateful for the technical assistance directly provided by the Fund and through the Pacific Financial Technical Assistance Center. My authorities welcome regular contact with the Fund and look forward to receiving the Fund's continued assistance. 


\section{RESERVE BANK OF FIJI \\ SUVA, FIJI}

Private Mail Bag, Suva

Cable: Resbank

Tolephone: (679) 3313611

Fax: $(679) 3301688$

Website: Www rbfgoy.fi

E-mail: rbeQreseryebank, gov,fi

\section{STATEMENT BY THE RESERYE BANK OF FIJI ON EXCHANGE CONTROLS}

The authorities agree with the staff's assessment of Fiji's economic situation. They also agree with the thrust of the report by the staff of the IMF. The authorities would like to complement the report by discussing in more detail the Fiji's exchange and capital controls.

Fiji accepted the IMF's Article VIII Agreement on 4 August 1974. Exchange control is administered by the Reserve Bank of Fiji acting as the agent of the Govemment under the Exchange Control Act.

Fiji maintains some exchange controls. These controls are necessary to safeguard the official foreign exchange reserves. Current account transactions are free of exchange control. There are restrictions on capital transactions. Fiji has progressively relaxed its exchange controls. All current account transactions are delegated to commercial banks and authorised foreign exchange dealers to execute. There are delegated limits on some current transactions. These limits are not controls to prevent outflows of foreign exchange. These limits are only an administrative boundary between foreign exchange regulation by the Reserve Bank and the cominercigi banks and authorized dealers. Bona fide transactions above these limits are subject to case-by-case approval by the Reserve Bank. Approval is generally granted, and the public is aware of this policy.

Since September 2000, the Reserve Bank of Fiji has progressively relaxed exchange controls. The documentation required for certain transactions have also been progressively reduced. This stance continued in 2001 and 2002 with the re-introduction of offshore investment facility, redelegation of certain exchange control approvals to commercial banks and authorised foreign exchange dealers and reinstatement of the forward foreign exchange cover. The limits on repatriation of dividends and profits are mainly to smooth the pattern of outflows over a period of time. However, any restrictions placed are not to prevent outflow altogether.

In view of the positive outlook for foreign reserves and strong macroeconomic fundamentals, there will be further exchange control relaxations froml January 2003 . This information will be posted on the Bark's website, www.rbf.goy.fi, shortly.

Regular reviews of exchange control policies are conducted. The Reserve Bank of Fiji is comunitted to further liberalising exchange controls. 